\title{
Annual Nutrient Loadings, \\ Primary Productivity, and \\ Trophic State of Lake Koocanusa, Montana and British Columbia, 1972-80
}

GEOLOGIGALSURVEY PROFESSIONALAAPER 1283

Prepared for the U.S. Army Corps of

Engineers, Seattle District

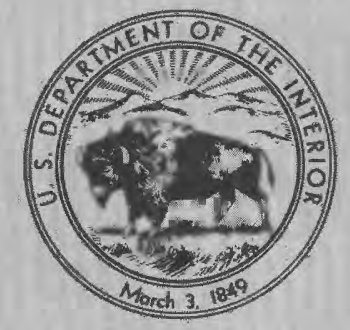





\section{Annual Nutrient Loadings, Primary Productivity, and Trophic State of Lake Koocanusa, Montana and British Columbia, 1972-80}

By PAUL F. WOODS

GEOLOGICAL S URVEY PROFESSIONAL PAPER 1283

Prepared for the U.S. Army Corps of

Engineers, Seattle District

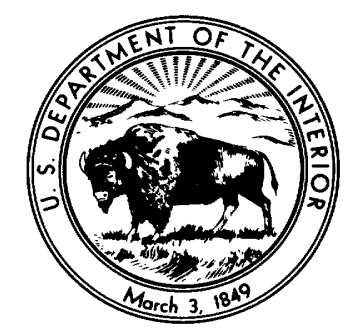

UNITEDSTATES GOVERNMENT PRINTING OFFICE, WASHINGTON : 1982 


\section{UNITED STATES DEPARTMENT OF THE INTERIOR}

JAMES G. WATT, Secretary

\section{GEOLOGICAL SURVEY}

Dallas L. Peck, Director

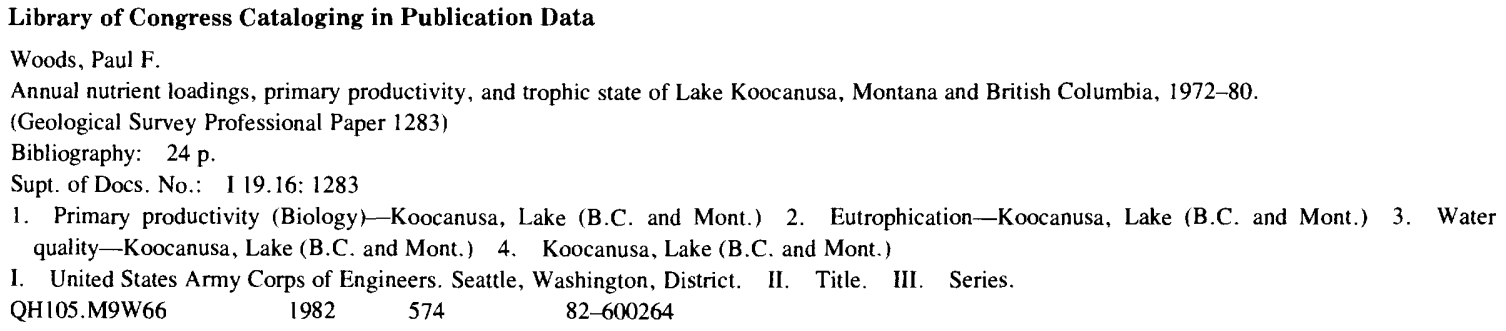




\section{CONTENTS}

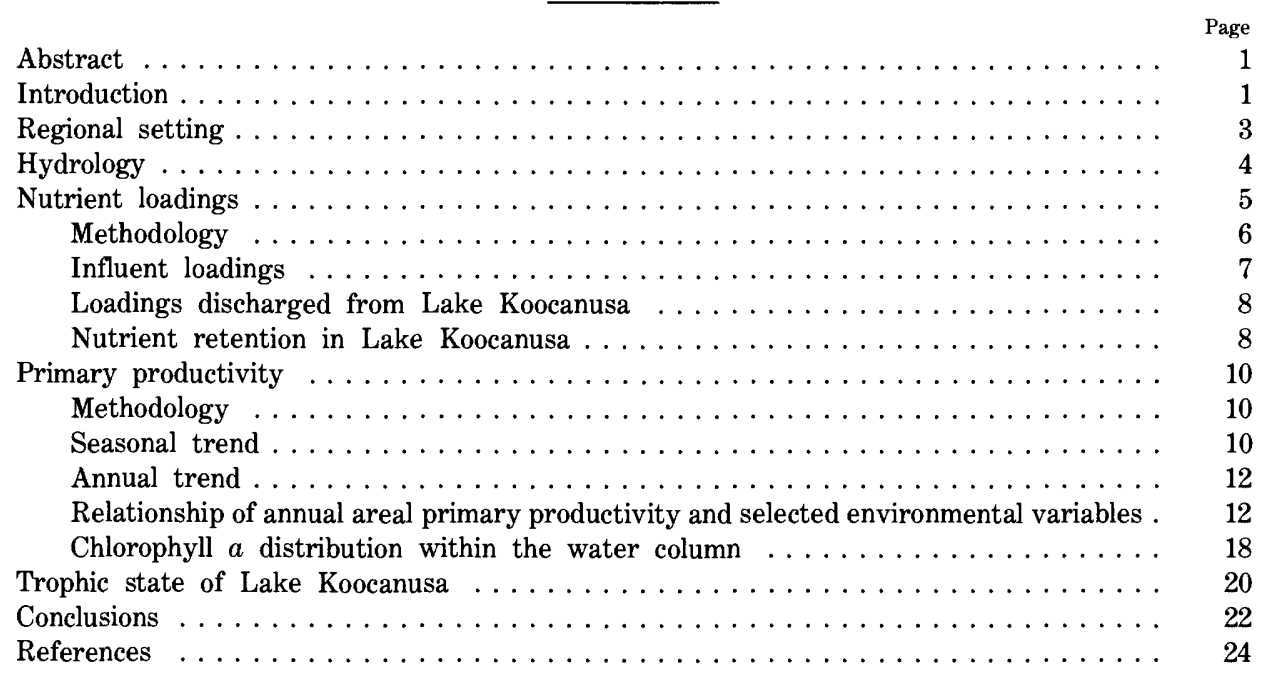

\section{ILLUSTRATIONS}

Figure 1. Map showing location of Kootenai River drainage basin and Lake Koocanusa $\ldots \ldots \ldots \ldots \ldots$

2-4. Graphs showing:

2. Monthly and annual inflow to and releases from Lake Koocanusa, $1972-80 \ldots \ldots \ldots \ldots$

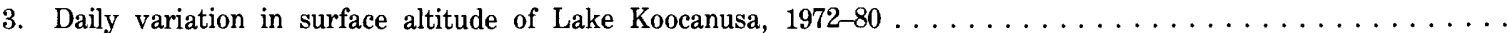

4. Daily values of areal primary productivity at the four limnological stations, Lake Koocanusa, 1972-80 . . . .

5. Scatterplots of annual areal primary productivity versus maximum and mean annual euphotic zone depths, annual areal phosphorus loading, and annual nitrogen retention coefficient for Lake Koocanusa, $1972-80 \ldots \ldots \ldots$

6. Graph showing annual variation of mean and maximum euphotic zone depths, areal primary productivity, areal phosphorus loading, and nitrogen retention coefficient for Lake Koocanusa, $1972-80$.

7. Typical diagram used to quantify the percentage distribution of chlorophyllawithin the water column of Lake Koocanusa. .

8. Graph showing application of Lake Koocanusa data in table 17 to Vollenweider total phosphorus loading and mean

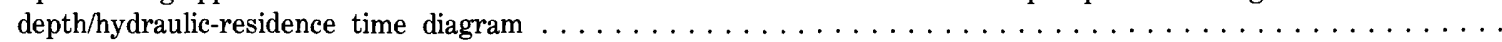

9. Graph showing application of Lake Koocanusa data in table 17 to Vollenweider total nitrogen loading and mean

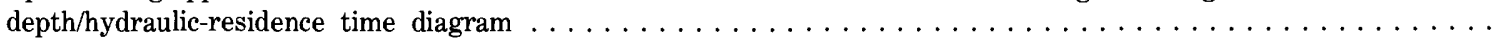




\section{TABLES}

TABLE 1. Annual precipitation at climatological station 1 and annual mean air temperature at climatological station $2,1972-80$.

2. Volume and surface area of Lake Koocanusa at selected reservoir surface altitudes $\ldots \ldots \ldots \ldots \ldots \ldots$

3. Lake-filling and hydraulic-residence times of Lake Koocanusa, $1972-80 \ldots \ldots \ldots \ldots \ldots \ldots \ldots$

4. Annual loadings of total phosphorus that entered Lake Koocanusa, $1970-80 \ldots \ldots \ldots \ldots \ldots$

5. Annual loadings of total nitrogen that entered Lake Koocanusa, $1970-80 \ldots \ldots \ldots \ldots \ldots \ldots$

6. Comparison of 1973-78 loadings of total phosphorus (TP) and total nitrogen (TN) at two stations on the St.

Mary River, one upstream and one downstream from the fertilizer plant at Kimberley, British Columbia .....

7. Annual loadings of total phosphorus (TP) and total nitrogen (TN) discharged from Lake Koocanusa, 1970-80 . . .

8. Nutrient-retention coefficients for total phosphorus and total nitrogen in Lake Koocanusa, $1972-80 \ldots \ldots \ldots \ldots . .$.

9. Statistical summary of daily areal primary productivity and euphotic zone depth at the four limnological stations, Lake

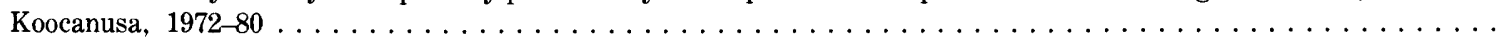

10. Statistical summary of daily areal primary productivity in Lake Koocanusa, $1972-80 \ldots \ldots \ldots \ldots \ldots$

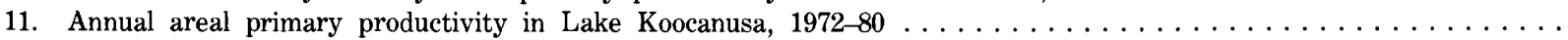

12. Statistical summary of environmental variables used in correlation and multiple regression analyses of annual areal

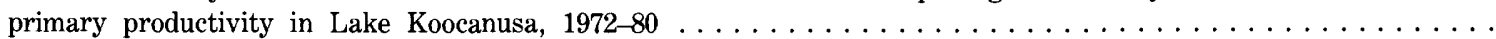

13. Correlation coefficients between annual areal primary productivity and environmental variables X1 through X12 ..

14. Multiple regression models for prediction of annual areal primary productivity in Lake Koocanusa ..........

15. Multiple regression model developed by Woods (1979) for prediction of daily areal primary productivity in Lake

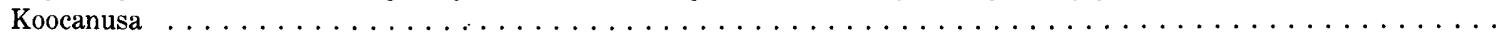

16. Percentage distribution of chlorophyll $a$ in three depth strata at the Forebay and Tenmile stations in $1980 \ldots \ldots$

17. Required data for using Vollenweider nutrient loading models to determine the trophic state of Lake Koocanusa .

\section{METRIC CONVERSION TABLE}

To convert International System (SI) of units in this report to inch-pound units, multiply by the following factors:

Multiply SI unit

cubic kilometer $\left(\mathrm{km}^{3}\right)$

cubic meter per second $\left(\mathrm{m}^{3} \cdot \mathrm{s}^{-1}\right)$

gram (g)

gram per square centimeter

$\left(\mathrm{g} \cdot \mathrm{cm}^{-2}\right)$

gram per square meter $\left(\mathrm{g} \cdot \mathrm{m}^{-2}\right)$

gram per square meter per year $\left(\mathrm{g} \cdot \mathrm{m}^{-2} \cdot \mathrm{a}^{-1}\right)$

hectare (ha)

kilogram per hectare per year $\left(\mathrm{kg} \cdot \mathrm{ha}^{-1} \cdot \mathrm{a}^{-1}\right)$

kilometer $(\mathrm{km})$

lux ( $\mathrm{x}$ )

meter $(\mathrm{m})$

megagram $(\mathrm{Mg})$

megagram per cubic kilometer $\left(\mathrm{Mg} \cdot \mathrm{km}^{-3}\right)$

milligram (mg)

milligram per cubic meter $\left(\mathrm{mg} \cdot \mathrm{m}^{-3}\right)$

milligram per square meter per day $\left(\mathrm{mg} \cdot \mathrm{m}^{-2} \cdot \mathrm{d}^{-1}\right)$

millimeter $(\mathrm{mm})$

square kilometer $\left(\mathrm{km}^{2}\right)$
By

$$
\begin{aligned}
& 8.107 \times 10^{5} \\
& 3.531 \times 10^{1} \\
& 2.205 \times 10^{-3} \\
& 2.049 \\
& \\
& 2.049 \times 10^{-4} \\
& 2.049 \times 10^{-4} \\
& \\
& 2.471 \\
& 8.922 \times 10^{-1} \\
& 6.214 \times 10^{-1} \\
& 9.290 \times 10^{-2} \\
& 3.281 \\
& 1.102 \\
& 1.359 \times 10^{-6} \\
& \\
& 2.205 \times 10^{-6} \\
& 6.245 \times 10^{-8}
\end{aligned}
$$

2.049

$3.937 \times 10^{-2}$

$3.861 \times 10^{-1}$
To obtain inch-pound unit

acre-foot

cubic foot per second

pound

pound per square foot

pound per square foot

pound per square foot per year

acre

pound per acre per year

mile

foot-candle

foot

ton (short)

ton (short) per acre- foot

pound

pound per cubic foot

pound per square foot per day

inch

square mile equation:

$$
{ }^{\circ} \mathrm{F}=1.8 \times{ }^{\circ} \mathrm{C}+32
$$

National Geodetic Vertical Datum of 1929 (NGVD of 1929): A geodetic datum derived from a general adjustment of the first-order level nets of both the United States and Canada, formerly called "mean sea level." NGVD of 1929 is referred to as sea level in this report. 


\title{
ANNUAL NUTRIENT LOADINGS, PRIMARY PRODUCTIVITY, AND TROPHIC STATE OF LAKE KOOCANUSA, MONTANA AND BRITISH COLUMBIA, 1972-80
}

\author{
By Paul F. WoOds
}

\section{ABSTRAC'I}

Limnological data collected at Lake Koocanusa were used to investigate the relationship of nutrient loadings, primary productivity, and trophic state of the reservoir during 1972-80. The reservoir, on the Kootenai River, was impounded by Libby Dam on March 21, 1972. Manipulation of the 7.16-cubic-kilometer reservoir for flood control, its primary function, created large fluctuations in reservoir volume and produced annual lake-filling times that ranged from 0.14 to 0.66 year.

Loadings of nitrogen and phosphorus prior to and following impoundment of Lake Koocanusa were found to be large enough to predict eutrophic conditions. Beginning in 1976, total phosphorus loadings, but not total nitrogen loadings, were substantially reduced following improvements in waste-water treatment at a fertilizer plant located upstream from the reservoir. The closure of Libby Dam substantially reduced loadings of nitrogen and phosphorus downstream from Lake Koocanusa. On the average, the reservoir retained 63 percent of its influent loading of total phosphorus and 25 percent of its influent loading of total nitrogen.

Daily areal and volumetric primary productivity varied widely in each year at four sampled limnological stations. During the 9 years studied, daily areal primary productivity, in milligrams of carbon fixed per square meter, ranged from 0.4 to 420.0 ; the mean of the 313 sampled days was 128.5. Annual areal primary productivity ranged from 23.2 to 38.5 grams of carbon fixed per square meter and thereby categorized Lake Koocanusa as oligotrophic.

The relationship of annual areal primary productivity and 12 selected environmental variables was determined by multiple regression analysis. One of the models that was derived used two variables-annual euphotic zone depth and annual areal phosphorus loading-and accounted for 62.0 percent of the variation in annual areal primary productivity.

The distribution of chlorophyll $a$ within the water column indicated that, on the average, more than one-half of the phytoplankton in the reservoir was beneath the euphotic zone. These results support the hypothesis that the reservoir's weak thermal structure had allowed circulation of phytoplankton out of the euphotic zone.

The trophic state of Lake Koocanusa was categorized as eutrophic when based on the relationship of the nutrient loadings and the reservoir's ratio of mean depth to hydraulic-residence time. This result conflicted with the oligotrophic ranking the reservoir received based on its areal primary productivity. The discrepancy in trophic state was attributed mainly to the failure of nutrient loading models to adequately account for physical processes within reservoirs. Part of the nutrient loading that entered Lake Koocanusa was unavailable to phytoplankton because the nutrients were carried beneath the euphotic zone by large volumes of interflow and underflow. Another part of the nutrient loading was adsorbed to suspended sediment and removed from the water column. Thus, phytoplankton primary productivity was controlled not only by nutrients, but also by other limnological processes.

\section{INTRODUCTION}

Libby Dam was constructed as part of a treaty between the United States and Canada to cooperatively develop the water resources of the Columbia River drainage basin. Construction of the dam on the Kootenai (spelled Kootenay in Canada) River began in 1966, and Lake Koocanusa was officially impounded on March 21, 1972. The reservoir has a volume of 7.16 $\mathrm{km}^{3}$ and provides flood storage, hydroelectric power production, and recreation benefits. The 148-km-long reservoir straddles the United States-Canadian border and impounds water from about $23,271 \mathrm{~km}^{2}$, or 47 percent, of the Kootenai River drainage basin (fig. 1). Three Canadian rivers, the Kootenai, Elk, and Bull, supply 87 percent of the reservoir's inflow (Bonde, 1979) and, therefore, exert a major influence on the limnology of Lake Koocanusa.

Preimpoundment water-quality studies indicated the presence of large concentrations of total phosphorus, orthophosphorus ${ }^{1}$, and total nitrogen in the Kootenai River, which were attributed to industrial point-source discharges in the Canadian part of the drainage basin (Bonde and Bush, 1975). Using the preimpoundment data, these authors calculated that the reservoir's surface would receive areal loadings of $10 \mathrm{~g} \cdot \mathrm{m}^{-2}$ of total phosphorus and $20 \mathrm{~g} \cdot \mathrm{m}^{-2}$ of total nitrogen. Areal nutrient loadings have been used in conjunction with mean depth and hydraulic residence time to estimate a water body's susceptibility to eutrophication (Vollenweider,

${ }^{1}$ Rigler (1973) reported that methodological problems preclude determination of the actual concentration of orthophosphate-phosphorus in natural water samples. He suggested use of the term "soluble reactive phosphorus" as a more accurate operational definition. However, the term orthophosphorus is retained for use in this report because it is the terminology currently used by the Geological Survey. 
1968, 1975). Application of Vollenweider's methods to $/$ rus and $8.0 \mathrm{~g} \cdot \mathrm{m}^{-2}$ of total nitrogen would be sufficient Lake Koocanusa by Bonde and Bush (1975) indicated to cause concern for eutrophication of the reservoir. that annual areal loadings of $2.0 \mathrm{~g} \cdot \mathrm{m}^{-2}$ of total phospho- $\mid$ These values were substantially less than the predicted

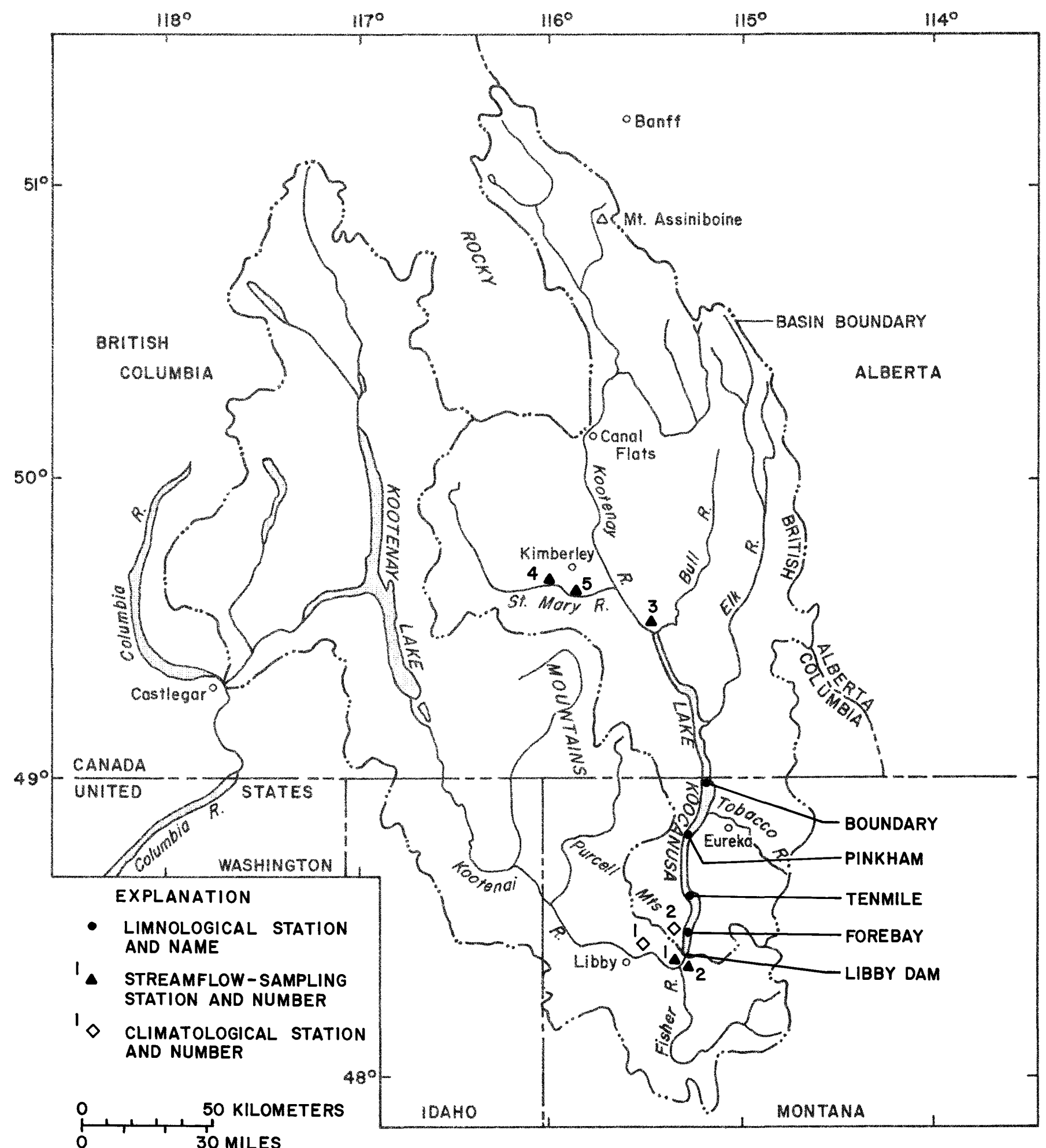

FIGURE 1.-Location of Kootenai River drainage basin and Lake Koocanusa. 
annual loadings; therefore, Bonde and Bush considered Lake Koocanusa to be susceptible to eutrophication. However, they cautioned that prediction of the actual response of the reservoir to such nutrient loadings would be difficult.

Bonde and Bush (1975) reported that blooms of Aphanizomenon flos-aquae, a blue-green alga characteristic of eutrophic waters, occurred in Lake Koocanusa in the autumns of 1974 and 1975 and considered these symptomatic evidence of eutrophication. However, Woods (1979) reported that annual primary productivity in the reservoir during 1972 through 1975 was characteristic of oligotrophic, not eutrophic, water bodies. Preliminary evaluations by Hobbie (1976) and Bush and Bonde (1977) revealed that primary productivity in Lake Koocanusa was predominantly controlled by physical limnological processes. Additional studies by Woods $(1979,1981)$ attributed the reservoir's oligotrophy to suppression of phytoplankton photosynthesis by circulation of phytoplankton out of the euphotic zone.

Subsequent to the 1972-75 period evaluated by Woods (1979), waste-water treatment was improved at the industrial point-source discharges in Canada. Beginning in 1976, these improvements resulted in substantial reductions in loadings of total phosphorus delivered into Lake Koocanusa (Bonde, 1979).

Although the limnological data collected during 1972 through 1975 have been evaluated (Woods, 1979, 1981; Woods and Falter, 1982), little such work has been done on the post-1975 data. The U.S. Army Corps of Engineers, therefore, requested that the U.S. Geological Survey further evaluate some selected data. The Corps of Engineers was primarily interested in furthering their understanding of the limnological processes that control the trophic state of Lake Koocanusa. Annual nutrient loadings and annual areal primary productivity were specified for intensive evaluation, because both have been extensively used to classify the trophic state of lakes and reservoirs.

The purpose of this resultant report is to categorize the trophic state of Lake Koocanusa based on annual nutrient loadings and annual areal primary productivity. Seasonal and annual trends in primary productivity are described, as well as annual trends in loadings of nitrogen and phosphorus. Control of annual areal primary productivity by selected limnological processes in Lake Koocanusa is evaluated in relation to results derived from multiple regression analyses and an analysis of the distribution of chlorophyll $a$ within the water column. The report addresses the $1972-80$ postimpoundment phase and is based on preimpoundment data collected after 1967 and postimpoundment data collected from 1972 through 1980.

\section{REGIONAL SETTING}

Lake Koocanusa lies within the Kootenai River drainage basin, an area of $49,987 \mathrm{~km}^{2}$ occupying parts of Idaho, Montana, and British Columbia. Altitudes in the basin range from $3,618 \mathrm{~m}$ above sea level at Mt. Assiniboine to $418 \mathrm{~m}$ at the confluence of the Kootenai and Columbia Rivers near Castlegar, British Columbia. The surface of Lake Koocanusa at maximum pool is at an altitude of $749.50 \mathrm{~m}$.

The Kootenai River, the principal tributary to Lake Koocanusa, arises $64 \mathrm{~km}$ west of Banff, Alberta, and flows southward to the Purcell Mountains. Near the Purcells, the river is impounded by Libby Dam $4.5 \mathrm{~km}$ upstream from the Fisher River. The Kootenai River eventually enters Kootenay Lake, and thence the Columbia River near Castlegar, British Columbia.

Between Canal Flats, British Columbia, and the Tobacco River, the Kootenai River flows along the Rocky Mountain Trench-a graben having a floor about $11 \mathrm{~km}$ wide and a vertical displacement of several hundred meters. The trench is partly filled with Pleistocene and Holocene deposits of unconsolidated silt, sand, and gravel into which the Kootenai River has incised about 60 to $90 \mathrm{~m}$ (Coffin, 1970). Except for the relatively flat terrain of the Rocky Mountain Trench, the topography upstream from Libby Dam is dominated by rugged mountains that are densely forested with conifers.

Climatically, the Kootenai River basin is subjected to maritime influences in the winter and continental influences in the summer. These influences, in conjunction with the mountainous terrain, result in complex weather patterns. The Rocky Mountain Trench receives

TABLE 1.-Annual precipitation at climatological station $1^{a}$ and annual mean air temperature at climatological station $2^{b}, 1972-80$

\begin{tabular}{|c|c|c|c|}
\hline \multirow{2}{*}{ Year } & \multicolumn{2}{|c|}{ Annual precipitation, in millimeters } & \multirow{2}{*}{$\begin{array}{c}\text { Annual mean } \\
\text { air temperature, } \\
\text { in degrees Celsius }\end{array}$} \\
\hline & Tota 1 & Departure from normal ${ }^{l}$ & \\
\hline 1972 & 485.6 & $-7 \cdot 2$ & 6.2 \\
\hline 1973 & 357.4 & -135.4 & 6.6 \\
\hline 1974 & 460.2 & -32.6 & 7.4 \\
\hline 1975 & 527.6 & +34.8 & 6.1 \\
\hline 1976 & 354.3 & -138.5 & 7.0 \\
\hline 1977 & 403.1 & -89.7 & 7.2 \\
\hline 1978 & 424.4 & -68.4 & 6.2 \\
\hline 1979 & 311.7 & -181.1 & 7.1 \\
\hline 1980 & 551.9 & +59.1 & 7.1 \\
\hline
\end{tabular}

aClimatological station 1 is "Libby 1 NE Ranger Station" in reports of the U.S. Department of Comerce (issued annuliy).

bClimatological station 2 is "Libby Dam" in reports of the U.S. Department of Commerce (issued annually).

cDeparture from long-term annual average precipitation of $492.8 \mathrm{~mm}$ for 83 years of record. 
an average of $400 \mathrm{~mm}$ of precipitation per year and is considered semiarid, whereas the Rocky Mountains annually receive an average of $1,000 \mathrm{~mm}$ of precipitation (Water Resources Service, 1976). About 70 percent of the basin's precipitation falls as snow during November through March (Bonde and Bush, 1975). At climatological station 1 (fig. 1), precipitation has been recorded for 83 years and temperature for 73 years (U.S. Department of Commerce, issued annually). Based on these data, the mean annual precipitation near Libby Dam is $492.8 \mathrm{~mm}$ and the mean annual temperature is $7.3^{\circ} \mathrm{C}$.

Annual precipitation and annual mean air temperatures recorded at climatological stations 1 and 2 (fig. 1) near Libby Dam during $1972-80$ are listed in table 1. Precipitation ranged from 311.7 to $551.9 \mathrm{~mm}$. Except for 1975 and 1980, precipitation was less than normal over the 9 years, particularly in 1973, 1976, and 1979 . Yearly variation in air temperature was small, ranging from $6.1^{\circ}$ to $7.4^{\circ} \mathrm{C}$, but the monthly values published by the U.S. Department of Commerce (issued annually) varied widely.

\section{HYDROLOGY}

The predominant flood-control function of Lake Koocanusa necessitates substantial reductions in volume during the autumn and winter to provide adequate capacity for spring snowmelt runoff. This operational schedule produces a wide range of reservoir volume and surface area (table 2). At maximum pool, the reservoir contains $7.16 \mathrm{~km}^{3}$ and has a surface area of about 188 $\mathrm{km}^{2}$. A drawdown of $52.4 \mathrm{~m}$ to minimum operational pool reduces the volume to $1.08 \mathrm{~km}^{3}$ and the surface

\begin{tabular}{|c|c|c|c|c|}
\hline $\begin{array}{l}\text { Surface } \\
\text { altitude, } \\
\text { in meters }\end{array}$ & $\begin{array}{l}\text { volume, in } \\
\text { cubic } \\
\text { kilometers }\end{array}$ & $\begin{array}{l}\text { Percent of } \\
\text { maximum } \\
\text { volume }\end{array}$ & $\begin{array}{c}\text { Surface area, } \\
\text { in square } \\
\text { kilometers }\end{array}$ & $\begin{array}{c}\text { Percent of } \\
\text { maximum } \\
\text { area }\end{array}$ \\
\hline${ }^{3} 749.50$ & 7.16 & 100.0 & 188.2 & 100.0 \\
\hline 740.00 & 5.52 & 77.1 & 159.4 & 84.7 \\
\hline 730.00 & 4.08 & 57.0 & 131.5 & 69.9 \\
\hline 720.00 & 2.91 & 40.6 & 103.2 & 54.8 \\
\hline 710.00 & 1.99 & 27.8 & 80.9 & 43.0 \\
\hline 700.00 & 1.26 & 17.6 & 64.8 & 34.4 \\
\hline$b_{697.08}$ & 1.08 & 15.1 & 59.1 & 31.4 \\
\hline 690.00 & .71 & 9.9 & 46.5 & 24.7 \\
\hline 680.00 & .34 & 4.7 & 27.5 & 14.6 \\
\hline 671.17 & .14 & 2.0 & 16.2 & 8.6 \\
\hline
\end{tabular}

a Maximum pool.

binimum operational pool.

${ }^{c}$ Dead storage. area to $59.1 \mathrm{~km}^{2}$.

Annual inflow to the reservoir exceeded or equaled annual outflow from Libby Dam except in 1977 and 1979 , the 2 years in which inflow was about one-half of normal (fig. 2). Maximum inflow occurred in May or June, whereas, in general, outflow was largest during reservoir drawdown. This cyclic pattern of inflow and outflow produced large fluctuations in reservoir volume and surface altitude (fig. 3). The reservoir surface generally was at its yearly maximum altitude in July, August, and September and at its minimum during March and April.

The reservoir attained its maximum surface altitude for less than 7 months during the 9 years graphed in figure 3. Three months was the longest period in which the reservoir surface was at a constant altitude. Most of the 9 years was characterized by a constantly changing reservoir surface altitude and, hence, volume.

Reservoir volume, inflow, and outflow can be related mathematically as lake- filling time and hydraulic-residence time. Lake-filling time represents the time required to replace the volume of a reservoir at a given inflow (Daley and others, 1981); whereas hydraulic-residence time represents the time required to replace the volume of a reservoir at a given outflow (Vollenweider, 1975). The two are calculated by the following equations:

$$
\begin{aligned}
& R=\frac{V}{I} \\
& F=\frac{V}{O}
\end{aligned}
$$

where

$R$ is lake-filling time, in years;

$F$ is hydraulic-residence time, in years;

$V$ is reservoir volume, in cubic kilometers;

$I$ is annual inflow, in cubic kilometers; and

$O$ is annual outflow, in cubic kilometers.

The theoretical lake-filling time of Lake Koocanusa is 0.67 year, based on a reservoir volume of $7.16 \mathrm{~km}^{3}$ and an assumed annual inflow of $10.65 \mathrm{~km}^{3}$. However, the reservoir experienced a large range in volume, inflow, and outflow from 1972 through 1980, which yielded annual lake-filling times that ranged from 0.14 to 0.66 year and annual hydraulic-residence times that ranged from 0.14 to 0.62 year (table 3). In addition to the annual variation, the reservoir exhibited monthly variation in volume, inflow, and outflow. Lake-filling and hydraulic-residence times, therefore, were calculated using monthly data instead of annual data. The results, in table 3 , indicated a wide range in values. For example, the mean monthly lake filling time in $\mathbf{1 9 7 6}$ was 0.71 year, but during that year, the value ranged from 0.13 to 1.54 years. The minimum value resulted 


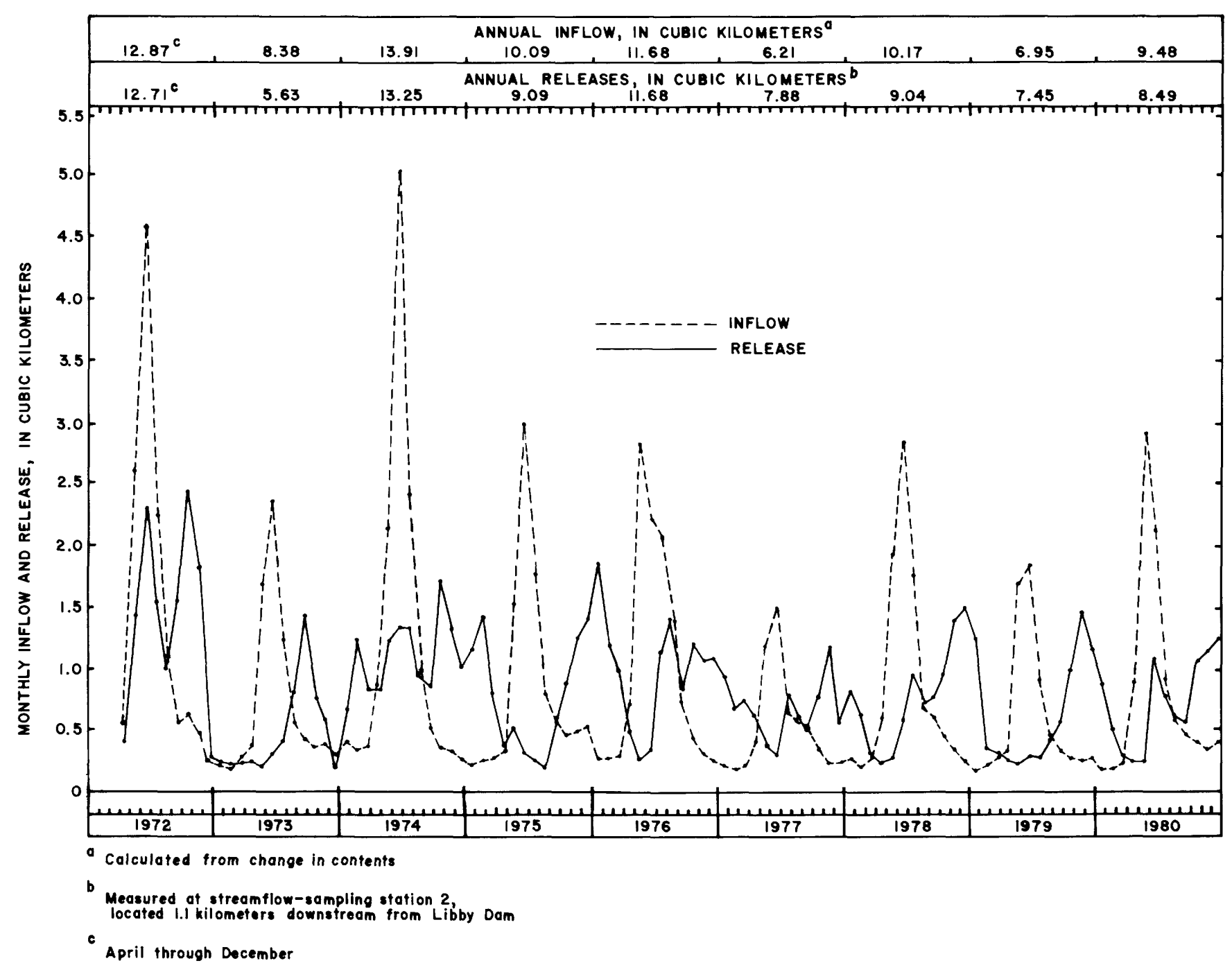

FIGURE 2.-Monthly and annual inflow to and releases from Lake Koocanusa, 1972-80.

from springtime snowmelt runoff entering a partly drawndown reservoir in May; the maximum lake-filling time of 1.54 years occurred in December as small inflow entered a large reservoir volume.

\section{NUTRIENT LOADINGS}

The relationship between nutrient loadings and the trophic state of a lake or reservoir has been extensively studied and was reviewed in recent reports by Rast and Lee (1978) and Reckhow (1979). A model developed by Vollenweider $(1968,1975)$ was discussed in these two reports. This model, based on areal loadings of total phosphorus or total nitrogen, mean depth, and hydraulic-residence time, plots a point onto a graph from which the trophic state of the lake or reservoir may be estimated. In Lake Koocanusa, loadings of both nutrients were large enough to produce a eutrophic ranking (Bonde and Bush, 1975).

The source of much of the phosphorus loading to Lake Koocanusa was a fertilizer plant near Kimberley, British Columbia (Bonde and Bush, 1975). Daley and others (1980) cited this plant as a major source of orthophosphate and, to a lesser degree, ammonia nitrogen that has entered Kootenay Lake, which is about 230 $\mathrm{km}$ downstream from Libby Dam. The plant, in operation since 1953, discharged wastes to the St. Mary River, a tributary of the Kootenai River. Fertilizer production was doubled in 1962 and again increased in 1965. Water pollution control at the plant was improved in 1969 , but it was not operating optimally until 1975 (Daley and others, 1980). The effect of the 1969 waterpollution control measures is evident in the history of orthophosphate loading in the Kootenai River at a station $6 \mathrm{~km}$ downstream from Libby Dam (streamflow- 
sampling station 1 , fig. 1). In $1968,3,259 \mathrm{Mg}$ of orthophosphate passed the station, but from 1969 to 1971 , the annual loading of orthophosphate was less than 900 $\mathrm{Mg}$ (Bonde and Bush, 1975).

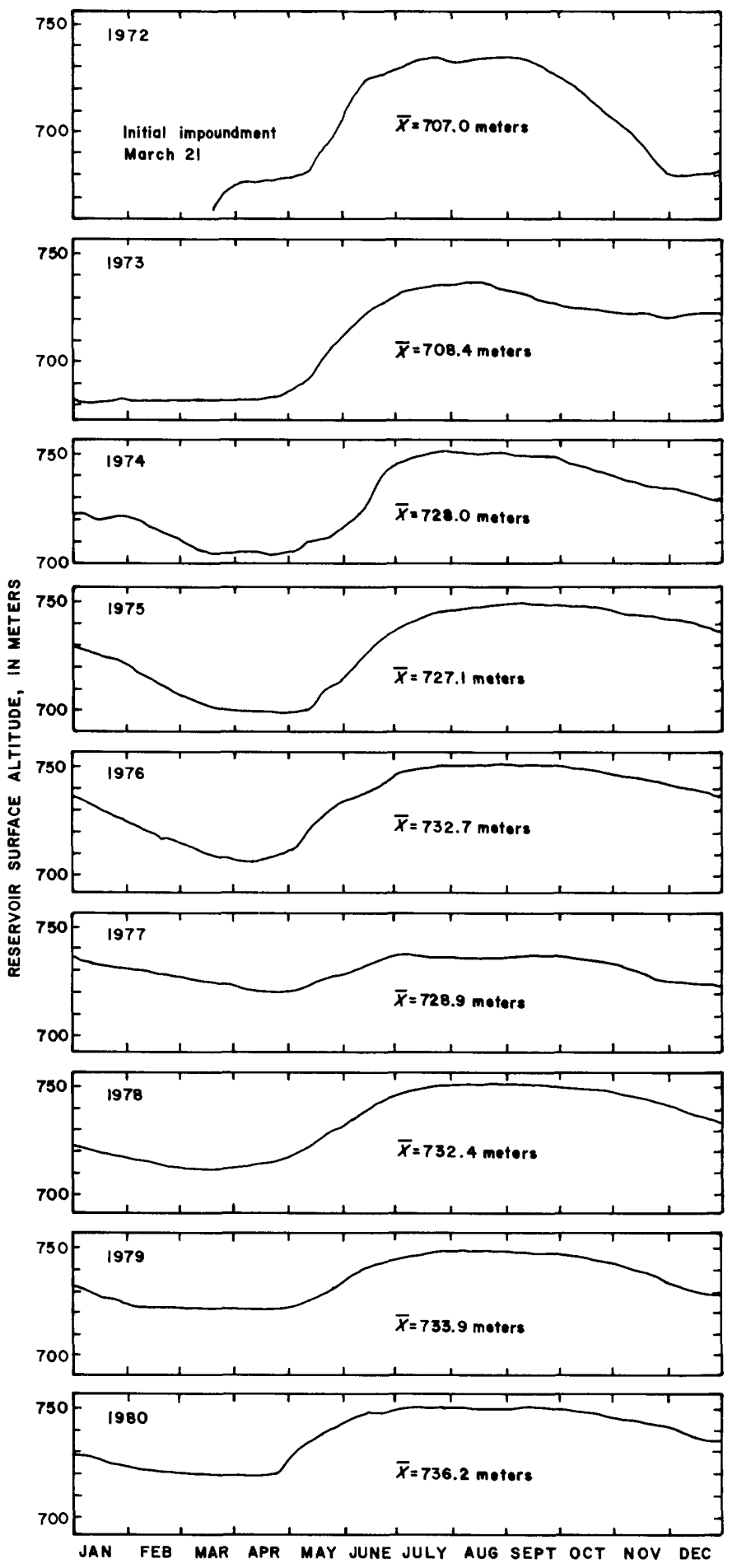

FIGURE 3.-Daily variation in surface altitude of Lake Koocanusa, 1972-80. $\overline{\mathrm{X}}$ denotes mean annual reservoir surface altitude, in meters.
TABLE 3.-Lake-filling and hydraulic-residence times of Lake Koocanusa, 1972-80

\begin{tabular}{|c|c|c|c|c|c|c|c|c|}
\hline \multirow{3}{*}{ Year } & \multicolumn{4}{|c|}{$\begin{array}{c}\text { Lake-filling time, } \\
\text { in years }\end{array}$} & \multicolumn{4}{|c|}{$\begin{array}{c}\text { Hydraullc-residence time, } \\
\text { in years }\end{array}$} \\
\hline & \multirow[b]{2}{*}{ Annua 1} & \multicolumn{3}{|c|}{ Monthly } & \multirow[b]{2}{*}{ Annual } & \multicolumn{3}{|c|}{ Monthly } \\
\hline & & Mean $^{a}$ & $\begin{array}{c}\text { Mini- } \\
\text { mum }\end{array}$ & $\underset{\text { mum }}{\operatorname{Maxi-}}$ & & Mean ${ }^{a}$ & $\underset{\text { mum }}{\text { Mini- }}$ & $\underset{\text { mum }}{\operatorname{Maxi-}}$ \\
\hline $1972^{b}$ & 0.14 & 0.17 & 0.04 & 0.52 & 0.14 & 0.14 & 0.02 & 0.37 \\
\hline 1973 & .22 & .40 & .10 & .88 & .33 & .49 & .11 & 1.29 \\
\hline 1974 & .28 & .61 & .09 & 1.28 & .29 & .33 & .13 & .67 \\
\hline 1975 & .37 & .63 & .11 & 1.13 & .41 & .78 & .10 & 2.66 \\
\hline 1976 & .38 & .71 & .13 & 1.54 & .38 & .55 & .13 & 1.56 \\
\hline 1977 & .64 & .93 & .26 & 1.64 & .50 & .59 & .24 & 1.42 \\
\hline 1978 & .43 & .75 & .18 & 1.33 & .48 & .63 & .24 & 1.28 \\
\hline 1979 & .66 & 1.08 & .22 & 1.78 & .62 & .97 & .22 & 2.08 \\
\hline 1980 & .52 & .94 & .17 & 1.47 & .58 & .78 & .29 & 2.07 \\
\hline
\end{tabular}

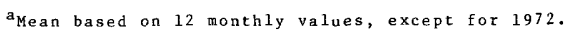

bapril through December on 1 y.

\section{METHODOLOGY}

Nutrient loadings that annually entered Lake Koocanusa were estimated to be the sum of loadings from gaged streamflow, ungaged drainage area, atmospheric deposition, and the Eureka sewage-treatment plant. Nutrient loadings from ground water and nutrient fluxes due to changes in reservoir bank storage were not quantified because of a lack of data.

The only nutrient loading estimated from gaged streamflow was for streamflow-sampling station 3 on the Kootenai River in British Columbia (fig. 1). The drainage area upstream from this station is $11,266 \mathrm{~km}^{2}$ and the streamflow includes the effluent from the fertilizer plant at Kimberley. Annual nutrient loadings from this station were summations of daily loadings that are calculated as follows:

where

$$
L=C \times Q \times f
$$

$L$ is daily loading, in megagrams;

$C$ is daily nutrient concentration, in milligrams per liter;

$Q$ is mean daily streamflow, in cubic meters per second; and

$f$ is 0.08640 , a factor to convert equation units to megagrams per day.

Daily nutrient concentrations were estimated from linear interpolation of nutrient concentrations actually measured in the gaged stream. Loadings of nutrients discharged from Lake Koocanusa were estimated with equation 3. The annual loadings of total phosphorus and total nitrogen that entered Lake Koocanusa prior to 
impoundment were estimated by Bonde and Bush (1975) in a manner similar to equation 3.

Nutrient loading from the $12,005 \mathrm{~km}^{2}$ of drainage area that was ungaged was estimated by the method of watershed-export coefficients of Reckhow, Beaulac, and Simpson (1980). Sufficient data were available from the Bull, Elk, and Tobacco Rivers to permit calculating loadings per unit area. Streamflow and water-quality data for 1972-77 were input to equation 3 and the results were summed to derive annual loadings of total phosphorus and total nitrogen. The annual loadings for each stream then were divided by their gaged drainage area. The median value of the derived watershed-export coefficients for the three streams was 0.144 $\mathrm{kg} \cdot \mathrm{ha}^{-1} \cdot \mathrm{a}^{-1}$ (range $=0.022-0.796$, number of samples $=$ 13) for total phosphorus and $1.35 \mathrm{~kg} \cdot \mathrm{ha}^{-1} \cdot \mathrm{a}^{-1}$ (range $=0.52-1.75$, number of samples $=14$ ) for total nitrogen. These two median watershed-export coefficients were multiplied by the ungaged drainage area of $1,200,502$ ha to obtain annual loadings of total phosphorus and total nitrogen in kilograms. These values then were multiplied by 0.001 to convert them into megagrams.

Atmospheric deposition of total phosphorus and total nitrogen received by the surface of Lake Koocanusa was estimated using the product of the reservoir's mean annual surface area in hectares, a forest-atmospheric input coefficient in kilograms per hectare per year, and a 0.001 factor which yielded annual loading in megagrams. Forest-atmospheric input coefficients were 0.27 $\mathrm{kg} \cdot \mathrm{ha}^{-1} \cdot \mathrm{a}^{-1}$ for total phosphorus and $0.99 \mathrm{~kg} \cdot \mathrm{ha}^{-1} \cdot \mathrm{a}^{-1}$ for total nitrogen - the only values cited in Reckhow, Beaulac, and Simpson (1980) that were judged by this author as geographically applicable to the study area. Mean annual surface area, in hectares, was derived from statistical analysis of daily measurements of surface altitude. Mean annual reservoir surface altitude was converted to surface area using area-capacity curves for Lake Koocanusa.

Loadings of total phosphorus and total nitrogen from the sewage-treatment plant at Eureka, Montana (fig. 1), were obtained from the U.S. Environmental Protection Agency (1977). Annual loadings of $1.8 \mathrm{Mg}$ of total phosphorus and $9.1 \mathrm{Mg}$ of total nitrogen were measured during 1975 at the Eureka plant.

Variations in annual loadings of total phosphorus and total nitrogen were due, in part, to variations in annual streamflow. To remove this effect, each annual loading was divided by its respective annual streamflow to obtain a loading rate per unit volume of streamflow, expressed as megagrams per cubic kilometer of streamflow.

The relationship between influent loadings of total phosphorus and total nitrogen and the loadings of these two nutrients discharged through Libby Dam was quantified with a nutrient-retention coefficient (Dillon and Rigler 1974), calculated thusly:

$$
C=1.0-\frac{E}{I}
$$

where

$C$ is a nutrient-retention coefficient;

$E$ is the mass of nutrient, in megagrams, discharged from the reservoir in a year; and

$I$ is the mass of nutrient, in megagrams, that entered the reservoir in a year.

\section{INFLUENT LOADINGS}

Listed in tables 4 and 5 for total phosphorus and total nitrogen are the annual loadings and loading rates per unit volume of streamflow that entered Lake Koocanusa via gaged streamflow, ungaged drainage area, atmospheric deposition, and the Eureka sewage-treatment plant. From 1972 through 1975, the influent loading of total phosphorus ranged from 1,188 to $1,626 \mathrm{Mg}$. A large reduction occurred in 1976; the 1976 loading of total phosphorus was 39.4 percent of that estimated for 1975. For 1977-80, the loading of total phosphorus varied from 362 to $498 \mathrm{Mg}$. The loading rate per unit volume of streamflow for total phosphorus generally followed the same trend as the annual loadings of total phosphorus. The changes in total loading of total phosphorus primarily resulted from changes in loadings from

TABLE 4.-Annual loadings of total phosphorus that entered Lake Koocanusa, $1970-80^{a}$

\begin{tabular}{lcccc}
\hline \multicolumn{3}{c}{ Loading, in megagrams } & & \\
\cline { 2 - 4 } Year & Tota1 b & Gaged inflow & Atmospheric & $\begin{array}{c}\text { Loading rate, in } \\
\text { megagrams per cubic } \\
\text { k1lometer of streamf 1ow }\end{array}$ \\
\hline 1970 & 1,905 & 1,905 & - & 255.1 \\
1971 & 1,924 & 1,924 & - & 162.1 \\
1972 & 1,188 & 1,011 & 2.0 & 92.2 \\
1973 & 1,626 & 1,449 & 2.1 & 194.1 \\
1974 & 1,485 & 1,307 & 3.4 & 106.8 \\
1975 & 1,304 & 1,126 & 3.4 & 129.2 \\
1976 & 514 & 336 & 3.7 & 44.0 \\
1977 & 362 & 184 & 3.4 & 58.3 \\
1978 & 498 & 320 & 3.7 & 49.0 \\
1979 & 416 & 238 & 3.8 & 59.8 \\
1980 & 428 & 250 & 4.0 & 45.2 \\
\hline
\end{tabular}

apreimpoundment loadings for 1970-71 calculated for streamflow-sampling station 1, located 6 kilometers downstream from Libby Dam.

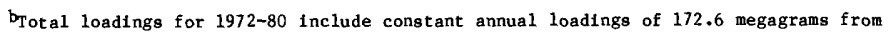
ungaged Inflow and 1.8 megagrans from Eureka sewage-treatment plant. 
TABLE 5.-Annual loadings of total nitrogen that entered Lake Koocanusa, $1970-80^{a}$

\begin{tabular}{lcccc}
\hline & \multicolumn{3}{c}{ Loading, in megagrans } & \\
\cline { 2 - 4 } Year & Total $^{\text {b }}$ & Gaged inflow & Atmospheric & $\begin{array}{c}\text { Loading rate, in } \\
\text { megagrams per cubic } \\
\text { kilometer of streamf1ow }\end{array}$ \\
\hline 1970 & 2,825 & 2,825 & -- & 378.3 \\
1971 & 4,057 & 4,057 & -- & 341.8 \\
1972 & 4,679 & 3,042 & 7.5 & 363.5 \\
1973 & 3,228 & 1,590 & 7.8 & 385.3 \\
1974 & 4,051 & 2,409 & 12.4 & 291.3 \\
1975 & 2,798 & 1,156 & 12.3 & 277.2 \\
1976 & 3,089 & 1,445 & 13.5 & 264.4 \\
1977 & 2,451 & 809 & 12.6 & 395.0 \\
1978 & 2,891 & 1,248 & 13.4 & 284.4 \\
1979 & 2,707 & 1,063 & 14.0 & 389.5 \\
1980 & 3,258 & 1,613 & 14.6 & 343.6 \\
\hline
\end{tabular}

aPreimpoundment loadings for $1970-71$ calculated for streamflow-sampling station

1, located 6 kilometers downstream from Libby Dam.

bTotal loadings for 1972-80 include constant annual loadings of 1,621 megagrams from ungaged inflow and 9.1 megagrams from Eureka sewage-treatment plant.

gaged streamflow, which reflected the reduced loadings of total phosphorus discharged by the fertilizer plant. Data on loadings of total phosphorus and total nitrogen during $1973-78$ in the St. Mary River upstream and downstream from the fertilizer plant (streamflow-sampling stations 4 and 5, fig. 1) readily showed the reduced loading of total phosphorus that commenced in 1976 (table 6). The loadings from the Eureka sewagetreatment plant and atmospheric deposition were too small to significantly alter the total loading. Ungaged drainage areas contributed a constant yearly load of $172.6 \mathrm{Mg}$ of total phosphorus. Variations in loadings from ungaged drainages may have significantly affected the total loading; however, such variations could not be estimated because of the lack of data.

The declining trend in influent loading that was readily apparent for total phosphorus did not occur for loadings of total nitrogen. During 1972-80, influent loadings of total nitrogen ranged from 2,451 to $4,679 \mathrm{Mg}$; nitrogen loading was not largely reduced in 1976 (table 5) as was total phosphorus loading. Variations in the loading of total nitrogen were primarily due to variations in loading of total nitrogen in gaged inflow, because ungaged inflow was estimated as a constant loading and loadings from the Eureka sewage-treatment plant and atmospheric deposition were too small to significantly affect total loading. The loading rate per unit volume of streamflow for total nitrogen showed no definite trend (table 5). Water-pollution-control measures instituted at the fertilizer plant apparently had little effect
TABLE 6.-Comparison of 1973-78 loadings of total phosphorus (TP) and total nitrogen (TN) at two stations on the St. Mary River, one upstream and one downstream from the fertilizer plant at Kimberley, British Columbia ${ }^{a}$

\begin{tabular}{|c|c|c|c|c|c|c|}
\hline \multirow[b]{3}{*}{ Year } & \multicolumn{4}{|c|}{ Annual loading, in megagrams } & \multirow{2}{*}{\multicolumn{2}{|c|}{$\begin{array}{l}\text { Percentage upstream } \\
\text { loading is of } \\
\text { downstream loading }\end{array}$}} \\
\hline & \multicolumn{2}{|c|}{ Upstream station $\mathrm{b}$} & \multicolumn{2}{|c|}{ Downstream stationc } & & \\
\hline & TP & TN & TP & $\mathrm{TN}$ & TP & $\mathbb{T N}$ \\
\hline 1973 & 8.1 & 175.4 & 1,806 & 532.5 & 22,270 & 303.7 \\
\hline 1974 & 15.5 & 264.1 & 1,671 & 937.3 & 10,770 & 354.9 \\
\hline 1975 & 7.9 & 196.1 & 1,215 & 579.4 & 15,340 & 295.4 \\
\hline 1976 & 10.5 & 259.0 & 459.4 & 433.4 & 4,388 & 167.3 \\
\hline 1977 & 3.6 & 125.0 & 165.2 & 291.3 & 4,538 & 233.0 \\
\hline 1978 & 8.9 & 178.1 & 226.5 & 411.2 & 2,548 & 230.9 \\
\hline
\end{tabular}

on the amount of total nitrogen carried per unit volume of streamflow, because loadings of total nitrogen upstream and downstream from the fertilizer plant did not substantially change during 1973-78 (table 6).

\section{LOADINGS DISCHARGED FROM LAKE KOOCANUSA}

After closure of Libby Dam in March 1972, loadings of total phosphorus substantially declined downstream from the dam; reductions in loading of total nitrogen were not as apparent, although some reduction occurred (table 7). Loading rates per unit volume of streamflow for total phosphorus and total nitrogen showed trends similar to those for their annual loadings. The variations in loading of total phosphorus and total nitrogen discharged from Lake Koocanusa were due, in part, to the water-pollution-control measures instituted at the fertilizer plant, which were previously discussed. However, the loadings that were input at the upstream end of the reservoir were subjected to sedimentation and chemical-biological transformations prior to their release from Libby Dam. Because of these two processes, variations in loads discharged from the dam cannot be directly attributed to variations in loads from the fertilizer plant.

\section{NUTRIENT RETENTION IN LAKE KOOCANUSA}

The combined effects within the reservoir on influent loadings of total phosphorus and total nitrogen were estimated with nutrient-retention coefficients (table 8). 
TABLE 7.-Annual loadings of total phosphorus (TP) and total nitrogen (TN) discharged from Lake Koocanusa, 1970-80 ${ }^{a}$

\begin{tabular}{ccccccc}
\hline & \multicolumn{2}{c}{ Loading, in megagrams } & & \multicolumn{2}{c}{$\begin{array}{c}\text { Loading rate, in megagrarns per } \\
\text { cubic kiloneter of streanf low }\end{array}$} \\
\cline { 2 - 3 } \cline { 5 - 6 } Year & TP & TN & & TP & TN \\
\hline 1970 & 1,905 & 2,825 & & 255.1 & 378.3 \\
1971 & 1,924 & 4,057 & & 162.1 & 341.8 \\
1972 & 997 & 4,004 & & 78.5 & 315.1 \\
1973 & 554 & 1,702 & & 98.5 & 302.5 \\
1974 & 706 & 3,378 & & 53.2 & 254.8 \\
1975 & 326 & 1,876 & & 35.9 & 206.3 \\
1976 & 359 & 2,529 & & 30.8 & 216.5 \\
1977 & 125 & 2,359 & & 15.9 & 299.4 \\
1978 & 82 & 2,229 & & 9.0 & 246.7 \\
1979 & 45 & 2,201 & & 6.1 & 295.3 \\
1980 & 50 & 1,626 & & 5.9 & 191.5 \\
\hline
\end{tabular}

apreimpoundnent loadings for 1970-71 calculated for streamflow-sampling station

1, located 6 kilometers downstream from Libby Dan; loadings for 1972-80 calculated for streamflow-sampling station 2, 1ocated 1.1 kiloneters downstream fron Libby Dam.

These coefficients indicate that total phosphorus was more readily retained in the reservoir than was total nitrogen. During 1972-80, an average of 63 per cent of influent total phosphorus was retained, whereas 25 percent of the total nitrogen loading was retained.

The large retention of total phosphorus in Lake Koocanusa was partly accounted for by the tendency for phosphorus to adsorb to clay minerals (Golterman 1975; Lee, 1970). Upstream from Lake Koocanusa, the Kootenai River traverses sedimentary and glacial deposits containing clay and silt (Crozier and Leinweber, 1975). Eroded sediments were transported into the reservoir and were deposited; part of the influent load of total phosphorus was, thereby, deposited. The efficiency of sediment trapping by reservoirs was empirically related to lake-filling time by Brune (1953). Based on Brune's graphs and Lake Koocanusa's theoretical lake-filling time of 0.67 year, the sediment trapping efficiency of the reservoir exceeds 95 percent. This value was verified by suspended-sediment measurements at streamflow-sampling stations 1 and 2, located downstream from Libby Dam. The average annual loading of suspended sediment per cubic kilometer of streamflow was $131,792 \mathrm{Mg}$ from 1968 through 1971 and $9,288 \mathrm{Mg}$ from 1972 through 1975. Postimpoundment loadings of suspended sediment, therefore, were reduced an average of $122,504 \mathrm{Mg}$, or by 93 percent, following impoundment of Lake Koocanusa.

The chemistry of phosphorus in Lake Koocanusa sediments was investigated by Iskandar and Shukla (1981). Their samples indicated a very small organic matter content, which they stated was characteristic of oligo-
TABLE 8.-Nutrient-retention coefficients for total phosporus and total nitrogen in Lake Koocanusa, 1972-80

\begin{tabular}{lcc}
\hline & \multicolumn{2}{c}{ Nutrient-retention coefficient } \\
\cline { 2 - 3 } Year & Total phosphorus & Total nitrogen \\
\hline 1972 & 0.16 & 0.14 \\
1973 & .66 & .47 \\
1974 & .52 & .17 \\
1975 & .75 & .33 \\
1976 & .30 & .18 \\
1977 & .66 & .04 \\
1978 & .84 & .23 \\
1979 & .89 & .19 \\
1980 & .88 & .50 \\
\hline
\end{tabular}

trophic lake sediments. The total phosphorus content of the silty clay sediments was composed of 87 to 98 percent inorganic phosphorus. These authors determined experimentally that the sediments had limited ability to adsorb additional phosphorus and the sediments desorbed only small amounts of phosphorus. Iskandar and Shukla concluded that Lake Koocanusa sediments function as a phosphorus sink. This conclusion appears reasonable because of the $7,821 \mathrm{Mg}$ of total phosphorus that entered the reservoir during $1972-80$, the reservoir discharged 3,244 $\mathrm{Mg}$ during the same period.

Part of the loading of total nitrogen also may have sorbed to clay minerals that were deposited in the reservoir. Although nitrate has little tendency to sorb to clay minerals (Lee, 1970), Keeney (1972) reported that organic nitrogen compounds readily sorb to clays and other inorganic colloids. During 1972-80, total nitrogen loading can be divided, on the average, into the following nitrogen forms: Nitrite plus nitrate, 45.6 percent; organic nitrogen, 43.1 percent; and ammonia, 8.2 percent. Presumably, less than 43.1 percent of the total nitrogen loading would have been adsorbed and deposited during 1972-80.

Further consideration of the retention of nitrogen and phosphorus loadings in Lake Koocanusa was difficult because both are nonconservative nutrients required by algae for photosynthesis and growth. The two nutrients are thereby involved in a complex sequence of uptake, utilization, and remineralization. For example, a bluegreen alga, Aphanizomenon flos-aquae, found in Lake Koocanusa has been reported by Fogg (1974) to fix atmospheric nitrogen and, thereby, may have provided an additional source of nitrogen to the reservoir. However, an undetermined amount of nitrogen was removed to the reservoir's sediment via denitrification reactions. Although the chemically and biologically induced processes that affect nitrogen and phosphorus within aqua- 
tic ecosystems are widely recognized, they are infrequently quantified. Detailed nutrient budgets that quantify these processes require data that were not available for Lake Koocanusa.

\section{PRIMARY PRODUCTIVITY METHODOLOGY}

Primary productivity was measured at the four limnological stations (fig. 1) commencing in late July 1972; sampling was discontinued at Pinkham after July 1976. Most of the 313 samples of primary productivity were obtained during May through October; only nine were taken in April and nine in November. Pinkham and Boundary generally were not sampled until late May or early June, because reservoir drawdown created insufficient depth for sampling prior to this time.

Primary productivity was measured with the carbon14 method for phytoplankton described by Greeson, Ehlke, Irwin, Lium, and Slack (1977). Five water samples were retrieved from depths at which the light intensity was equal to or larger than 0.1 percent of that incident at the reservoir surface. Light measurements were made with an unfiltered submersible photometer immediately prior to retrieval of the water samples. The water samples were then transferred to light and dark BOD bottles and inoculated with radioactive carbonate $\left({ }^{14} \mathrm{CO}_{3}{ }^{-2}\right)$. They were then incubated for 3 to 4 hours at the depth from which they were withdrawn. The light intensities used for incubation generally included five of the following seven values: $90,60,30$, $15,5,1$, and 0.1 percent. During the study, incubations generally were conducted during the period spanning 0900 to 1500 hours.

The value calculated for each water sample represents daily primary productivity, expressed as milligrams of carbon fixed per cubic meter $\left(\mathrm{mg} \cdot \mathrm{C} \cdot \mathrm{m}^{-3}\right)$. Values of daily primary productivity measured within the sampled depth profile were integrated to obtain daily areal primary productivity, expressed as milligrams of carbon fixed per square meter $\left(\mathrm{mg} \cdot \mathrm{C} \cdot \mathrm{m}^{-2}\right)$.

Only primary productivity by phytoplankton was measured in this study. No estimates of periphyton primary productivity were available for Lake Koocanusa. However, in large and deep lakes one generally can assume that the majority of annual primary productivity is by phytoplankton (Likens, 1975).

Annual areal primary productivity, in grams of carbon fixed per square meter $\left(\mathrm{g} \cdot \mathrm{C} \cdot \mathrm{m}^{-2}\right)$, was estimated for Lake Koocanusa to permit comparisons with other lakes and reservoirs. Annual areal primary productivity was calculated by integrating the area under a curve defined by values of total daily primary productivity for the reservoir. The total daily values were derived with the following equation :

$$
A=\left(R_{F} \times P_{F}\right)+\left(R_{T} \times P_{T}\right)+\left(R_{P} \times P_{P}\right)+\left(R_{B} \times P_{B}\right)
$$

where

$A$ is total daily primary productivity, in grams of carbon fixed per square meter;

$R_{F}$ is daily primary productivity, in grams of carbon fixed per square meter, at Forebay station (fig. 1);

$R_{T}$ is daily primary productivity, in grams of carbon fixed per square meter, at Tenmile station;

$R_{P}$ is daily primary productivity, in grams of carbon fixed per square meter, at Pinkham station;

$R_{B}$ is daily primary productivity, in grams of carbon fixed per square meter, at Boundary station;

$P_{F}$ is fraction of reservoir surface area associated with Forebay primary productivity value;

$P_{T}$ is fraction of reservoir surface area associated with Tenmile primary productivity value;

$P_{P}$ is fraction of reservoir surface area associated with Pinkham primary productivity value; and

$P_{B}$ is fraction of reservoir surface area associated with Boundary primary productivity value.

Days on which primary productivity was measured were used in equation 5; however, samples were not taken during much of the winter so this period required estimation. Based on primary productivity measurements at Forebay in November and December, the following estimates of daily areal primary productivity, in grams of carbon fixed per square meter, were used for each limnological station during winter months: November, December, and March, 0.01; January and February, 0.005. The months of April through July occasionally lacked a measured value of daily areal primary productivity at one or more limnological stations. In such instances, the average daily areal primary productivity at the limnological station during the missing month was used as input to equation 5 .

\section{SEASONAL TREND}

Daily areal primary productivity varied considerably among limnological stations and years and ranged from 0.4 to $420.0 \mathrm{mg} \cdot \mathrm{C} \cdot \mathrm{m}^{-2}$ (table 9 ). Statistical tests used to detect significant differences among limnological stations and years were not performed because of differences in the period sampled at each limnological station. Instead, the mean, minimum, and maximum values of daily areal primary productivity for each month are given (table 9). With the four limnological stations combined, August had the largest mean daily areal primary productivity and November had the smallest.

Mean values of daily areal primary productivity for April through June were substantially smaller at 
TABLE 9.-Statistical summary of daily areal primary productivity and euphotic zone depth at the four'limnological stations, Lake Koocanusa, 1972-80

\begin{tabular}{|c|c|c|c|c|c|c|c|c|}
\hline \multirow[b]{2}{*}{ Station } & \multirow[b]{2}{*}{ Month } & \multicolumn{3}{|c|}{$\begin{array}{c}\text { Daily areal pri- } \\
\text { mary productivity, } \\
\text { in milligrams of carbon } \\
\text { fixed per } \\
\text { square meter }\end{array}$} & \multicolumn{3}{|c|}{$\begin{array}{c}\text { Euphotic zone depth, } \\
\text { in meters }\end{array}$} & \multirow{2}{*}{$\begin{array}{l}\text { Number } \\
\text { of } \\
\text { Samples }\end{array}$} \\
\hline & & Mean & Minimum & Maximum & Mean & Minimum & Maximum & \\
\hline \multirow[t]{5}{*}{ Boundary } & June & 82.6 & 0.4 & 150.0 & 4.9 & 0.4 & 11.4 & 9 \\
\hline & $\mathrm{Ju} 1 \mathrm{y}$ & 135.1 & 75.0 & 340.0 & 7.3 & 2.1 & 12.2 & 17 \\
\hline & Aug. & 179.7 & 96.0 & 290.0 & 9.6 & 5.8 & 13.5 & 15 \\
\hline & Sept. & 136.4 & 20.0 & 230.0 & 10.2 & 5.5 & 16.0 & 17 \\
\hline & oct. & 90.3 & 24.0 & 220.0 & 8.7 & 5.9 & 14.8 & 15 \\
\hline \multirow[t]{8}{*}{ Pinkham } & Apr. & 75.0 & 75.0 & 75.0 & 1.4 & 1.4 & 1.4 & 1 \\
\hline & May & 10.2 & .5 & 36.0 & 1.1 & .4 & 1.8 & 6 \\
\hline & June & 83.0 & 18.0 & 230.0 & 2.8 & 1.1 & 4.9 & 5 \\
\hline & $\mathrm{Ju} 1 \mathrm{y}$ & 119.7 & 28.0 & 270.0 & 5.1 & 1.7 & 7.8 & 7 \\
\hline & Aug. & 131.0 & 86.0 & 170.0 & 8.4 & 5.4 & 10.7 & 6 \\
\hline & Sept. & 154.3 & 96.0 & 250.0 & 9.7 & 8.5 & 10.5 & 6 \\
\hline & oct. & 65.7 & 24.0 & 120.0 & 7.6 & 5.8 & $10 \cdot 3$ & 7 \\
\hline & Nov. & 6.7 & 1.4 & 12.0 & 4.8 & .5 & 9.2 & 2 \\
\hline \multirow[t]{8}{*}{ Tenmile } & Apr. & 119.8 & 57.0 & 250.0 & 2.6 & 1.4 & 3.7 & 4 \\
\hline & May & 109.4 & 16.0 & 390.0 & 4.6 & .6 & 9.5 & 14 \\
\hline & June & 171.3 & 100.0 & 280.0 & 5.8 & 1.7 & 10.7 & 15 \\
\hline & $\mathrm{Ju} 1 \mathrm{y}$ & 147.7 & 41.0 & 220.0 & 8.0 & 2.3 & 14.5 & 15 \\
\hline & Aug. & 152.2 & 43.0 & 220.0 & 11.3 & 5.9 & 18.0 & 16 \\
\hline & Sept. & 138.2 & 20.0 & 230.0 & 12.5 & 8.5 & 18.4 & 17 \\
\hline & $0 c t$. & 109.1 & 44.0 & 200.0 & 11.7 & 7.7 & 19.8 & 16 \\
\hline & Nov. & 20.0 & 5.1 & 43.0 & 7.2 & 4.9 & 11.2 & 3 \\
\hline \multirow[t]{8}{*}{ Forebay } & Apr. & 168.5 & 23.0 & 340.0 & 4.0 & 2.7 & 4.7 & 4 \\
\hline & May & 139.4 & 62.0 & 320.0 & 6.0 & 2.3 & 11.2 & 14 \\
\hline & June & 165.1 & 92.0 & 400.0 & 6.3 & 2.3 & 10.8 & 15 \\
\hline & July & 141.9 & 12.0 & 370.0 & 7.8 & 1.8 & 12.2 & 16 \\
\hline & Aug. & 171.2 & 63.0 & 420.0 & 11.4 & 7.1 & 18.0 & 16 \\
\hline & Sept & 126.3 & 37.0 & 190.0 & 11.8 & 9.0 & 16.0 & 15 \\
\hline & oct. & 107.3 & 40.0 & 230.0 & 11.0 & 7.6 & 16.8 & 15 \\
\hline & Nov. & 31.0 & 3.2 & 69.0 & 5.2 & 3.7 & 7.9 & 4 \\
\hline \multirow[t]{8}{*}{ A 11} & Apr. & 136.4 & 23.0 & 340.0 & 3.1 & 1.4 & 4.7 & 9 \\
\hline & May & 104.2 & .5 & 390.0 & 4.5 & .4 & 11.2 & 34 \\
\hline & June & 141.0 & .4 & 400.0 & 5.5 & .4 & 11.4 & 44 \\
\hline & $\mathrm{Ju} 1 \mathrm{y}$ & 138.6 & 12.0 & 370.0 & 7.4 & 1.7 & $14 \cdot 5$ & 55 \\
\hline & Aug. & 163.4 & 43.0 & 420.0 & 10.5 & 5.4 & 18.0 & 53 \\
\hline & Sept. & 136.2 & 20.0 & 250.0 & 11.3 & 5.5 & 18.4 & 55 \\
\hline & oct. & 97.7 & 24.0 & 230.0 & 10.1 & 5.8 & 19.8 & 54 \\
\hline & Nov. & 22.0 & 1.4 & 69.0 & 5.8 & .5 & 11.2 & 9 \\
\hline A 11 & $-\mathrm{Nov}$ & 128.5 & .4 & 420.0 & 8.3 & .4 & 19.8 & 313 \\
\hline
\end{tabular}


Boundary and Pinkham than at Tenmile and Forebay. This condition is attributed to the fact that areal primary productivity is dependent on euphotic zone depth and the depths of the euphotic zone during April through June were smallest at Boundary and Pinkham. Mean euphotic zone depths during April and May at Pinkham were equal to or less than $1.4 \mathrm{~m}$, whereas they were equal to or greater than $2.6 \mathrm{~m}$ at Tenmile and Forebay. Although not measured in April and May, euphotic zone depths at Boundary probably were similar to those at Pinkham. The shallow euphotic zones during April and May occurred when the reservoir received large loadings of suspended sediment that were reported by Bonde and Bush (1975) to be historically carried by the Kootenai River during spring runoff.

The monthly based means for daily areal primary productivity in table 9 failed to show the variation among years; such variation is evident in table 10 . Because sampled periods did not coincide, statistical tests were not used to locate significant differences among the years. Mean daily areal primary productivity varied from 106.7 to $165.5 \mathrm{mg} \cdot \mathrm{C} \cdot \mathrm{m}^{-2}$, but the overall range during the 9 years was 0.4 to $420.0 \mathrm{mg} \cdot \mathrm{C} \cdot \mathrm{m}^{-2}$. The variation in daily areal primary productivity within each year at the four limnological stations is apparent from figure 4 . No common pattern among stations or years could be discerned, owing to the wide variation in daily areal primary productivity. Such variation was due to the effect of environmental variables on daily areal primary productivity; however, evaluation of the effects of such variables on daily areal primary productivity was beyond the scope of this report.

\section{ANNUAL TREND}

Annual areal primary productivity ranged from 23.2 to 38.5 and averaged $29.5 \mathrm{~g} \cdot \mathrm{C} \cdot \mathrm{m}^{-2}$ during $1972-80$ (table 11). The 95-percent confidence interval for the mean was determined to be 25.6 to $33.4 \mathrm{~g} \cdot \mathrm{C} \cdot \mathrm{m}^{-2}$. The years with annual primary productivity outside of the confidence interval included 1973-76 and 1980.

Primary productivity in Lake Koocanusa can be compared to general ranges of phytoplankton primary productivity of lakes in various trophic categories that were listed in Wetzel (1975). Wetzel listed mean primary productivity, in milligrams of carbon fixed per square meter per day, which is identical to average daily areal primary productivity listed in table 11 . Three of the trophic categories listed by Wetzel (1975), based on mean primary productivity, in milligrams of carbon fixed per square meter per day, were: Oligotrophic, 50-300; mesotrophic, 250-1,000; and eutrophic, greater than 1,000. Lake Koocanusa was clearly in the oligotrophic category, based on its average daily areal primary productivity that ranged from 63.6 to 105.5 $\mathrm{mg} \cdot \mathrm{C} \cdot \mathrm{m}^{-2}$ (table 11$)$.
TABLE 10.-Statistical summary of daily areal primary productivity in Lake Koocanusa, 1972-80

\begin{tabular}{|c|c|c|c|c|c|c|}
\hline \multirow[b]{2}{*}{ Year } & \multirow{2}{*}{\multicolumn{2}{|c|}{$\begin{array}{l}\text { Period } \\
\text { sampled }\end{array}$}} & \multicolumn{3}{|c|}{$\begin{array}{c}\text { Datly areal primary productivity, } \\
\text { in milligrams of carbon fixed } \\
\text { per square meter }\end{array}$} & \multirow{2}{*}{$\begin{array}{c}\text { Number of } \\
\text { samples }\end{array}$} \\
\hline & & & Mean & Minínur & Maximum & \\
\hline 1972 & July & 24 - Nov. 15 & 122.8 & 1.4 & 290.0 & 19 \\
\hline 1973 & Apr. & 24 - Nov. 30 & 120.5 & .5 & 390.0 & 28 \\
\hline 1974 & Apr. & 23 - Nov. 20 & 106.7 & 2.1 & 400.0 & 51 \\
\hline 1975 & Apr. & $16-0 \mathrm{ct} \cdot 30$ & 115.5 & .4 & 320.0 & 48 \\
\hline 1976 & Apr. & $12-$ oct. 28 & 114.1 & 23.0 & 420.0 & 39 \\
\hline 1977 & May & $4-$ Oct. 26 & 139.8 & 20.0 & 280.0 & 30 \\
\hline 1978 & May & $5-0_{c t} \cdot 25$ & 146.2 & 80.0 & 230.0 & 33 \\
\hline 1979 & May & $15-o_{c t} \cdot 17$ & 143.6 & 62.0 & 370.0 & 32 \\
\hline 1980 & May & 14 - Oct. 16 & 165.5 & 45.0 & 340.0 & 33 \\
\hline
\end{tabular}

\section{RELATIONSHIP OF ANNUAL AREAL PRIMARY PRODUCTIVITY AND SELECTED ENVIRONMENTAL VARIABLES}

Variations in annual areal primary productivity are caused by numerous environmental variables that directly or indirectly control the primary productivity of phytoplankton. The relationship of environmental variables and annual areal primary productivity in Lake Koocanusa was investigated with correlation and multiple regression analyses. Annual-based values for $12 \mathrm{en}-$ vironmental variables (table 12 ) were derived from the data base for use in these statistical analyses. Although table 12 is not an exhaustive listing, each of the 12 variables has a direct or indirect causal relationship with phytoplankton primary productivity.

Correlation coefficients for each environmental vari-

TABLE 11.-Annual areal primary productivity in Lake Koocanusa, 1972-80

\begin{tabular}{lcc}
\hline Year & $\begin{array}{c}\text { Annual areal } \\
\text { primary productivity, } \\
\text { in grams of carbon fixed } \\
\text { per square meter }\end{array}$ & $\begin{array}{c}\text { Average daily areal } \\
\text { primary productivty, } \\
\text { in milligrans of carbon } \\
\text { fixed per square meter }\end{array}$ \\
\hline $1972^{\text {a }}$ & 27.1 & 74.2 \\
1973 & 38.5 & 105.5 \\
1974 & 25.3 & 69.3 \\
1975 & 24.4 & 66.8 \\
1976 & 23.2 & 63.6 \\
1977 & 30.6 & 83.8 \\
1978 & 30.7 & 84.1 \\
1979 & 30.0 & 82.2 \\
1980 & 35.3 & 96.7 \\
$1972-80$ & 29.5 & 80.7 \\
\hline
\end{tabular}

a Includes March 21 to December 31. 


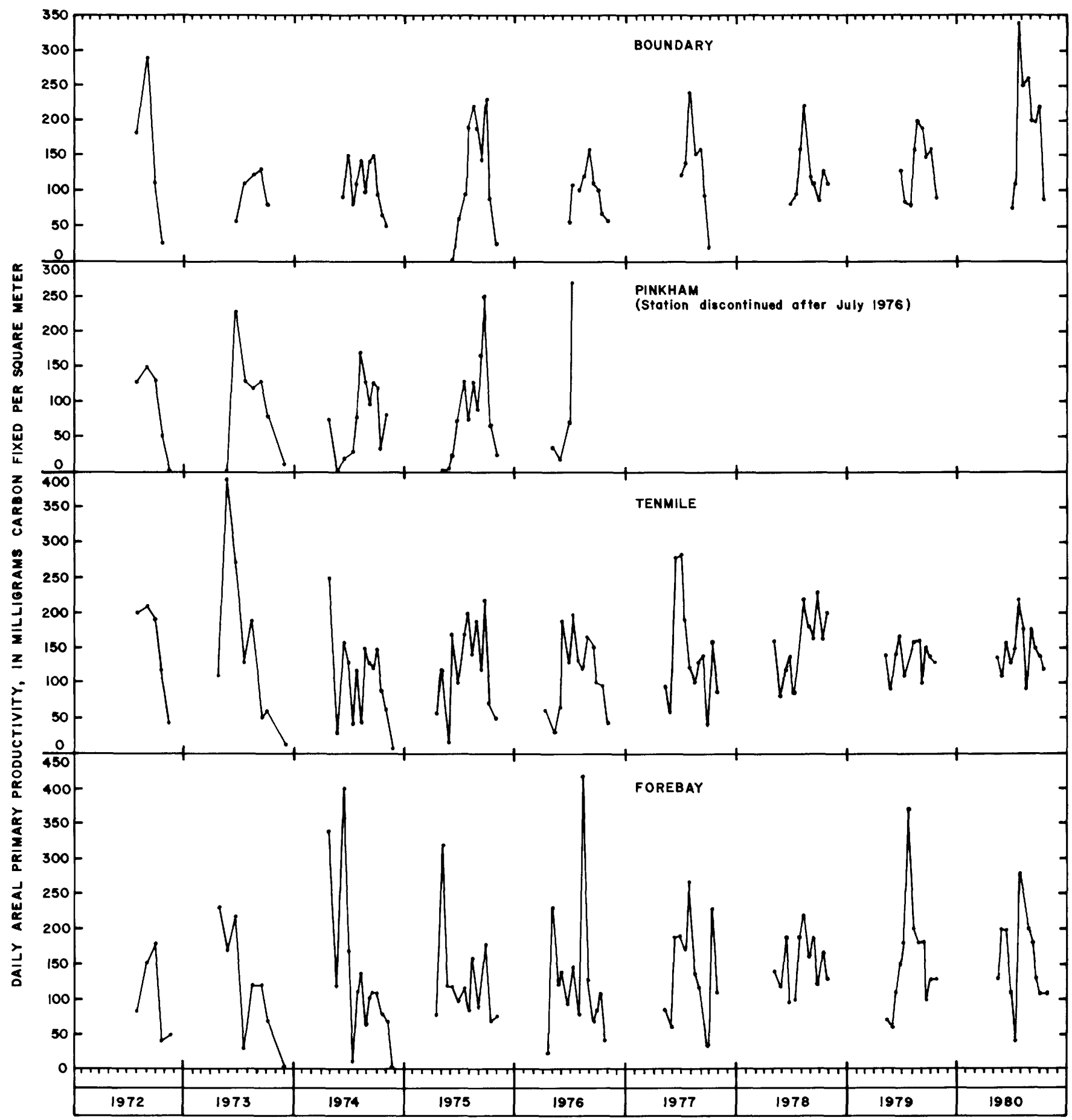

FIGURE 4.-Daily values of areal primary productivity at the four limnological stations, Lake Koocanusa, 1972-80.

able and annual areal primary productivity are listed in table 13. The two largest correlation coefficients exceeded 0.500 and were for annual nitrogen retention coefficient (X12) and mean annual euphotic zone depth (X1). However, none of the correlation coefficients were significantly different from 0.00 when judged against a significance level of 0.05 or less. Therefore, no single environmental variable was usable as a predictor of annual areal primary productivity. Combinations of the 12 environmental variables, therefore, were analyzed by multiple linear regression analysis, using annual areal primary productivity as the dependent variable.

Variable combinations were initially screened with the RSQUARE procedure of the Statistical Analysis 
TABLE 12.-Statistical summary of environmental variables used in correlation and multiple regression analyses of annual areal primary productivity in Lake Koocanusa, 1972-80

\begin{tabular}{|c|c|c|c|c|}
\hline $\begin{array}{l}\text { Vari- } \\
\text { able } \\
\text { no. }\end{array}$ & Var1able label & Mean & Minimum & Maximum \\
\hline $\mathrm{Y}$ & $\begin{array}{l}\text { Annual area1 primary productivity, in } \\
\text { grams carbon fixed per square meter }\end{array}$ & 29.5 & 23.2 & 38.5 \\
\hline $\mathrm{xl}$ & Mean annual euphotic zone depth, in meters & 8.5 & 5.9 & 12.5 \\
\hline $\mathrm{x} 2$ & $\begin{array}{l}\text { Maximum annual euphotic zone depth, in } \\
\text { meters }\end{array}$ & 13.8 & 10.7 & 19.8 \\
\hline$x_{3}$ & $\begin{array}{l}\text { Mean annual water temperature at } 3 \text { meters } \\
\text { depth, in degrees Celsius }\end{array}$ & 14.6 & 12.2 & 16.7 \\
\hline $\mathrm{x} 4$ & $\begin{array}{l}\text { Maximum annual water temperature at } 3 \\
\text { meters depth, in degrees Celsius }\end{array}$ & 20.5 & 18.8 & 22.0 \\
\hline $\mathrm{x} 5$ & Mean monthly lake fllling time, in years & .69 & .17 & 1.08 \\
\hline $\mathrm{x} 6$ & $\begin{array}{l}\text { Range of monthly lake filling time, in } \\
\text { years }\end{array}$ & 1.14 & .48 & 1.56 \\
\hline $\mathrm{x} 7$ & $\begin{array}{l}\text { Mean monthly hydraulic residence time, } \\
\text { in years }\end{array}$ & .58 & .14 & .97 \\
\hline $\mathrm{x} 8$ & $\begin{array}{l}\text { Range of monthly hydraulic residence } \\
\text { time, in years }\end{array}$ & 1.33 & .36 & 2.57 \\
\hline $\mathrm{x} 9$ & $\begin{array}{l}\text { Annual areal phosphorus loading, in } \\
\text { grams per square meter }\end{array}$ & 8.3 & 2.8 & 20.7 \\
\hline $\mathrm{x} 10$ & $\begin{array}{l}\text { Annual areal nitrogen loading, in } \\
\text { grams per square meter }\end{array}$ & 29.1 & 19.1 & 61.7 \\
\hline $\mathrm{x} 11$ & Annual phosphorus retention coefficient & .63 & .16 & .89 \\
\hline $\mathrm{x} 12$ & Annual nitrogen retention coefficient & .25 & .04 & .50 \\
\hline
\end{tabular}

System (SAS Institute, Inc., 1979). This computer procedure determines all possible linear regressions for a dependent variable and a set of independent variables, and then lists the coefficient of multiple correlation for each regression. Although 12 independent variables were available, there were only nine observations on each variable, which required that less than nine variables be used in each regression. Based on the advice of R. K. Steinhorst (University of Idaho, oral commun., 1981), only two- and three-variable regressions were developed from the data base. Those two- and threevariable regressions with the largest coefficient of multiple determination were selected for further analysis using the GLM procedure in the Statistical Analysis System. This computer procedure provides the parameter estimates for a regression model, the analysis of variance table, hypothesis tests, and residuals.

The two- and three-variable regression models that were derived from the 12 environment variables and that had the largest coefficient of multiple determination are listed in table 14 . In the two-variable model, annual areal primary productivity varied directly with mean annual euphotic zone depth and annual areal phosphorus loading. In the three-variable model, the dependent variable varied directly with mean annual euphotic zone depth and annual nitrogen retention coefficient and it varied inversely with maximum annual euphotic zone
TABLE 13.-Correlation coefficients between annual areal primary productivity and environmental variables $X 1$ through $X 12^{a}$

[Number of samples is nine]

\begin{tabular}{ccc}
\hline $\begin{array}{l}\text { Var1- } \\
\text { able } \\
\text { no. }\end{array}$ & $\begin{array}{c}\text { Correlation } \\
\text { coefficient }\end{array}$ & \multicolumn{1}{c}{$\begin{array}{c}\text { significance level of } \\
\text { correlation coeffictent }\end{array}$} \\
\hline $\mathrm{x} 1$ & 0.522 & 0.150 \\
$\mathrm{x} 2$ & .355 & .349 \\
$\mathrm{x} 3$ & .392 & .296 \\
$\mathrm{x} 4$ & .418 & .263 \\
$\mathrm{x} 5$ & .100 & .800 \\
$\mathrm{x} 6$ & -.106 & .786 \\
$\mathrm{x} 7$ & .187 & .630 \\
$\mathrm{x} 8$ & -.012 & .976 \\
$\mathrm{x} 9$ & .185 & .633 \\
$\mathrm{x} 10$ & .043 & .913 \\
$\mathrm{x} 11$ & .493 & .178 \\
$\mathrm{x} 12$ & .605 & .084 \\
\hline
\end{tabular}

avariables defined in table 12 .

depth. Mean annual euphotic zone depth was the dominant independent variable in both regression models, based on the relative magnitude of standardized partial regression coefficients. The two regression models account for 62.0 and 78.4 percent of the variation in the dependent variable. The overall regression models and their partial regression coefficients were significantly different from 0.00 at significance levels less than 0.061 .

The residuals for each regression model were graphically analyzed according to methods of Draper and Smith (1966). These analyses revealed no apparent violations in the assumptions of regression analysis. Scatter plots of each independent variable and the dependent variable exhibited linear trends; therefore, the independent variables were not transformed.

The two regression models in table 14 provided an empirical method for predicting annual areal primary productivity in Lake Koocanusa. The models were developed with a statistical technique that only quantifies the variation between dependent and independent variables. The method does not prove the existence of cause-and-effect relationships between the variables. The relationships may be spurious if the variables varied systematically, but independent of one another. Therefore, the two regression models were examined further to determine if cause-and-effect relationships were plausible between the dependent and independent variables. Correlations between the dependent and independent variables were examined with scatterplots (fig. 5) and the temporal variation of the variables was plotted (fig. 6) to assess systematic covariation.

Mean annual euphotic zone depth, the dominant variable in both regression models, was directly related to 
TABLE 14.--Multiple regression models for prediction of annual areal primary productivity in Lake Koocanusa

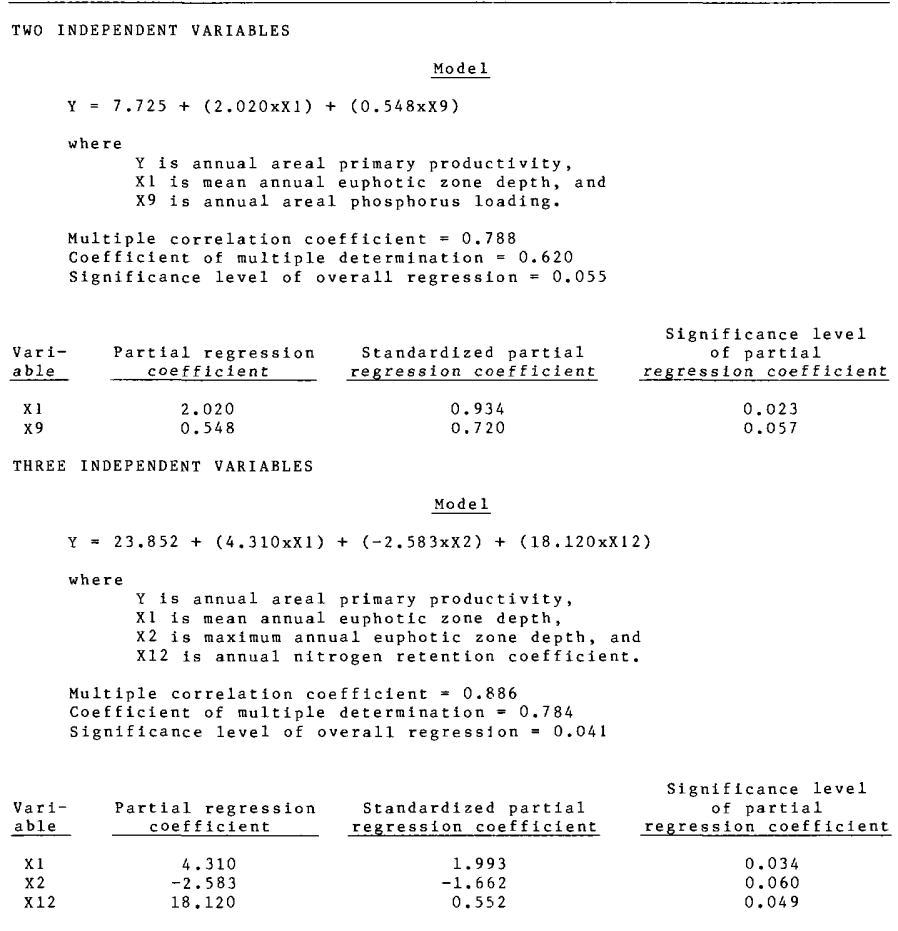

annual areal primary productivity (table 14). This relationship appeared plausible because areal primary productivity might be expected to increase if the depth of the euphotic zone increased. Mean annual euphotic zone depth plotted a positive linear trend with annual areal primary productivity, although the value for 1973 appeared to be outside of the trend (fig. 5). Over time, mean annual euphotic zone depth had an increasing trend similar to that of annual areal primary productivity, excepting the large 1973 value of the latter variable (fig. 6).

Maximum annual euphotic zone depth was inversely related to annual areal primary productivity in the three-variable regression model (table 14). This result does not seem plausible because mean and maximum euphotic zone depths were positively correlated (correlation coefficient $=0.953$, significance level less than 0.0001 , number of samples $=9$ ) and, therefore, would be expected to affect annual areal primary productivity in a similar manner. Maximum annual euphotic zone depth plotted a positive linear trend with annual areal primary productivity, although the values for 1973 and 1979 appeared to plot outside of the trend (fig. 5). Similar temporal trends, excepting 1973 , were exhibited by maximum annual euphotic zone depth and annual areal primary productivity (fig. 6). Based on this conflicting evidence, the occurrence of this variable in the regression model appeared to be spurious.

Annual areal phosphorus loading was directly related to annual areal primary productivity in the two-variable regression model (table 14). The relationship appeared to be plausible because increased phosphorus loading might be expected to result in increased annual areal primary productivity. The scatterplot of annual areal phosphorus loading showed a positive linear trend, which was due largely to the location of the 1973 value (fig. 5). If the 1973 value were deleted, the trend would likely have been negatively linear. Annual areal phosphorus loading had a decreasing trend with time (fig. 6 ), as would be expected from the reductions in total phosphorus loading listed in table 4. During 1972-76 and 1977-79, annual areal phosphorus loading and annual areal primary productivity covaried systematically, which largely explains the direct relationship derived by the regression modeling technique.

In the three-variable regression model, annual nitrogen retention coefficient was directly related to annual areal primary productivity (table 14). This relationship appeared to be intuitively correct, because additional retention of nitrogen might be expected to increase annual areal primary productivity. However, the positive linear trend in the scatterplot (fig. 5) was produced by the values for 1973 and 1980; if these two were not present, the trend would have been negatively linear. Figure 6 shows that the annual nitrogen retention coefficient varied sporadically with time, but during 197274 and 1979-80 it varied systematically with annual areal primary productivity. The inclusion of annual nitrogen retention coefficient into the regression model appeared to be largely dependent upon the bias created by its two largest values, which corresponded to the two largest values of annual areal primary productivity.

Of the four independent variables, only mean annual euphotic zone depth appeared likely to have a causeand-effect relationship with annual areal primary productivity. The direct relationships of annual areal phosphorus loading and annual nitrogen retention coefficient with annual areal primary productivity were strongly biased by the coincidence of their largest values. The inverse relationship of maximum annual euphotic zone depth and annual areal primary productivity was deemed spurious because it was intuitively incorrect.

Mean annual euphotic zone depth was indicative of the depth of light penetration into Lake Koocanusa. The attenuation of light by water can be quantified with an extinction coefficient that composites effects due to absorption of light by water and the scattering of light by suspended and dissolved matter. The extinction coef- 


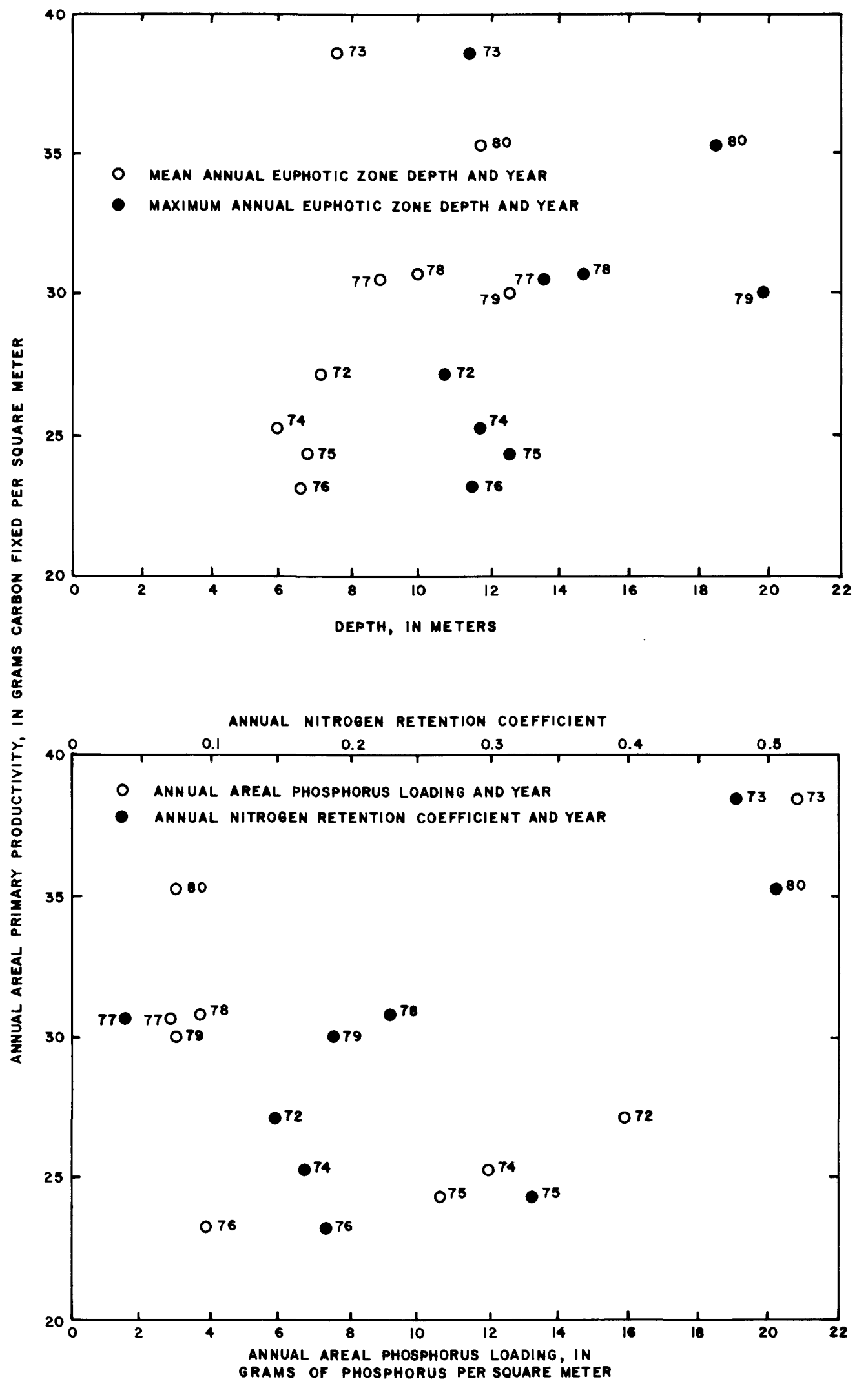

Figure 5.-Scatterplots of annual areal primary productivity versus maximum and mean annual euphotic zone depths, annual areal phosphorus loading, and annual areal nitrogen retention coefficient for Lake Koocanusa, 1972-80. 

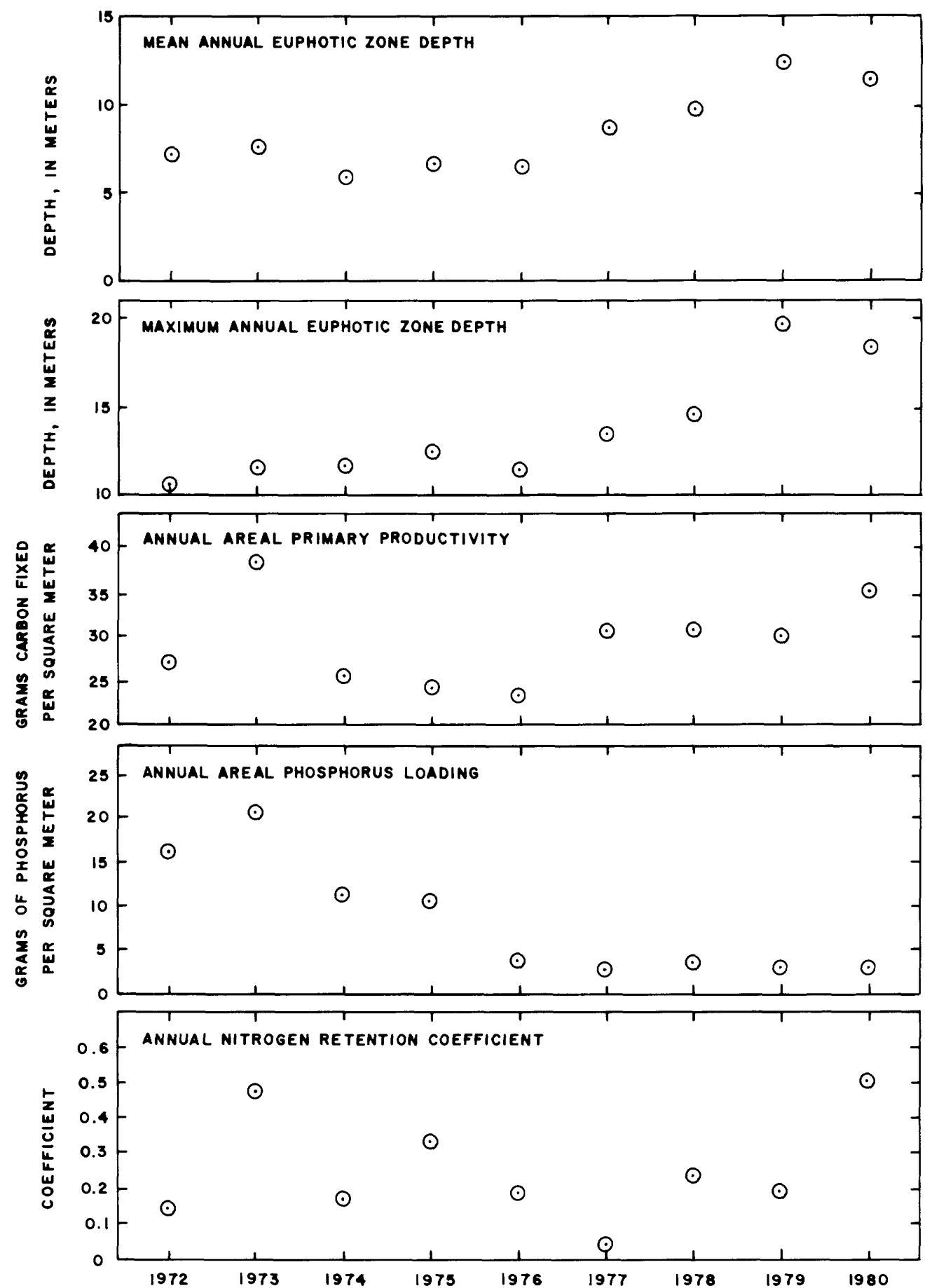

FigURE 6.-Annual variation of mean and maximum euphotic zone depths, areal primary productivity, areal phosphorus loading, and nitrogen retention coefficient for Lake Koocanusa, 1972-80.

ficient within the euphotic zone of Lake Koocanusa and the surface illumination were independent variables in a multiple regression derived by Woods (1979) to pre-dict daily areal primary productivity measured in Lake Koocanusa from 1972 to 1975 . Woods used 93 daily values instead of the 9 annual values reported here. The regression model is listed in table 15; derivation of the variables was discussed by Woods (1979). The regression model showed that daily areal primary productivity was inversely related to euphotic extinction coefficient and directly related to surface illumination. These relationships appeared plausible because a reduction in euphotic zone depth caused by an increase in euphotic extinction coefficient would likely reduce daily 
TABLE 15.-Multiple regression model developed by Woods (1979) for prediction of daily areal primary productivity in Lake Koocanusa

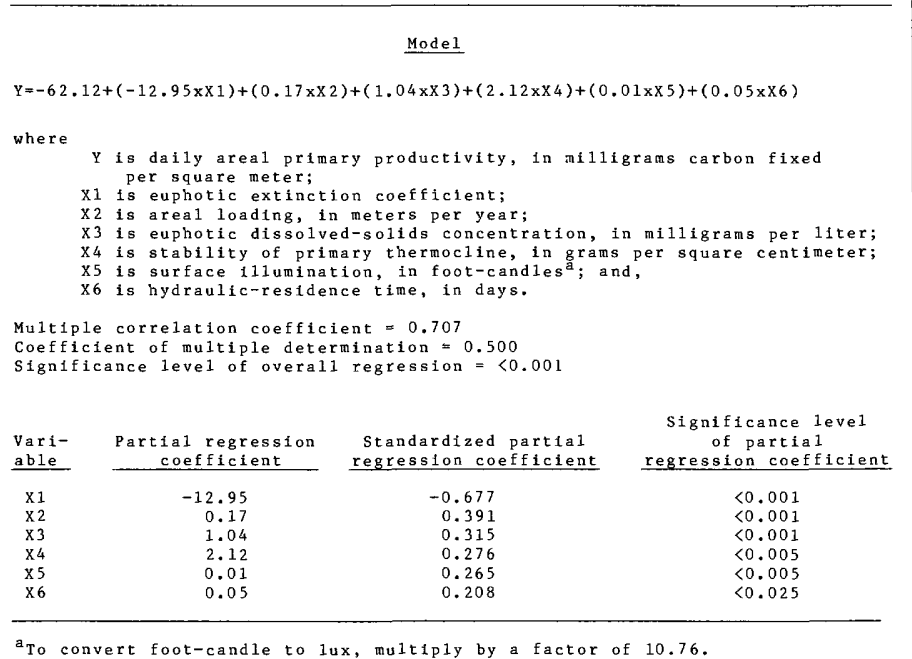

${ }^{a}$ To convert foot-candle to 1 ux, multiply by a factor of 10.76 .

areal primary productivity; increased surface illumination should increase daily areal primary productivity. Results of multiple regression analyses for daily and annual values were consistent in that variables related to light penetration into the euphotic zone were important predictors of areal primary productivity.

Woods (1979) concluded from analyses of data collected from 1972-75 at Lake Koocanusa that the quantity of light received by phytoplankton was the major environmental influence on primary productivity in the reservoir-although no single environmental variable accounted for all variation. Three processes were identified as having had an effect on the light available to phytoplankton. First, a weak thermal structure in the reservoir allowed phytoplankton to be circulated out of the euphotic zone into light conditions inadequate for photosynthesis to exceed respiration. The operational schedule of the reservoir, in conjunction with large seasonal inflow and outflow, produced the weak thermal structure. Second, the largely turbid inflows during spring runoff substantially reduced euphotic zone depths and, thereby, intensified the problem of light limitation experienced by phytoplankton that was circulated out of the euphotic zone. Third, the phytoplanktonic light environment was largely dependent upon seasonally and meteorologically induced variations in incident solar radiation.

The foregoing conclusions of Woods (1979) also may be applicable to the environmental control of daily areal primary productivity during $1976-80$ in Lake Koocanusa. However, the data analyses necessary to determine the environmental control of daily areal primary productivity during $1976-80$ were beyond the scope of this report. Evaluation of the relationship of daily values of primary productivity in conjunction with concurrent values for physical, chemical, and biological variables likely would yield valuable insight into the reasons why Lake Koocanusa was oligotrophic during $1972-80$, in spite of its potentially eutrophic loadings of nitrogen and phosphorus.

\section{CHLOROPHYLL $a$ DISTRIBUTION WITHIN THE WATER COLUMN}

Based on his analysis of data collected during 1972-75 at Lake Koocanusa, Woods (1979) hypothesized that phytoplankton was circulated beneath the euphotic zone. To test this hypothesis the limnological sampling program at Lake Koocanusa was modified in the 1980 water year. In that chlorophyll $a$ is a primary photosynthetic pigment found in all algae (Wetzel, 1975), its distribution in the water column was used to test this hypothesis. Such tests were not feasible prior to 1980 because chlorophyll $a$ was not sampled beneath the euphotic zone prior to 1980 . In 1980 , however, chlorophyll $a$ was sampled at two points beneath the euphotic zone-one each at two and three times the depth of 0.1 percent light. In addition, five samples of chlorophyll $a$ were collected in the euphotic zone-one each at the carbon-14 incubation depths. Prior to midMay 1978 chlorophyll $a$ in Lake Koocanusa was analyzed according to methods of Slack, Averett, Greeson, and Lipscomb (1973). This procedure did not correct for the degradation products of chlorophyll $a$; hence, one could not ascertain if the results were representative of living or dead chlorophyll-bearing organisms. Following mid-May 1978, chlorophyll $a$ sampled from Lake Koocanusa was determined according to methods of Greeson, Ehlke, Irwin, Lium, and Slack (1977). These results indicated the amount of chlorophyll $a$ that was contained in living chlorophyllbearing organisms.

Chlorophyll a concentrations were sampled at Forebay and Tenmile in 1980. The volume of chlorophyll $a$ in each of three depth strata then was determined from a plot of chlorophyll $a$ concentration versus depth (fig. 7). The percentage of the total volume of chlorophyll $a$ in the sampled water column then was determined for each of the three depth strata. The three depth strata were as follows: Surface to 1.0 percent light depth, 1.0 percent to 0.1 percent light depth, and 0.1 percent light depth to a depth equal to the depth of 0.1 percent light plus one-half of the depth difference between 1.0 percent and 0.1 percent light depth. The 1.0 percent light depth was chosen as the lower boundary of the upper stratum because the 1.0 percent light depth is often defined as the lower boundary of the euphotic zone (Greeson and others, 1977). 
The 0.1 percent light depth was chosen as a boundary because it was often the depth at which the lowermost carbon-14 sample was incubated in Lake Koocanusa.

The percentage of chlorophyll $a$ in each stratum varied during the sampled interval; the 95-percent confi- dence intervals indicate that the middle stratum varied less than the other two strata (table 16). The mean percentage distribution of chlorophyll $a$ in the three strata was similar at both limnological stations. On the average, less than one-half of the sampled chlorophyll

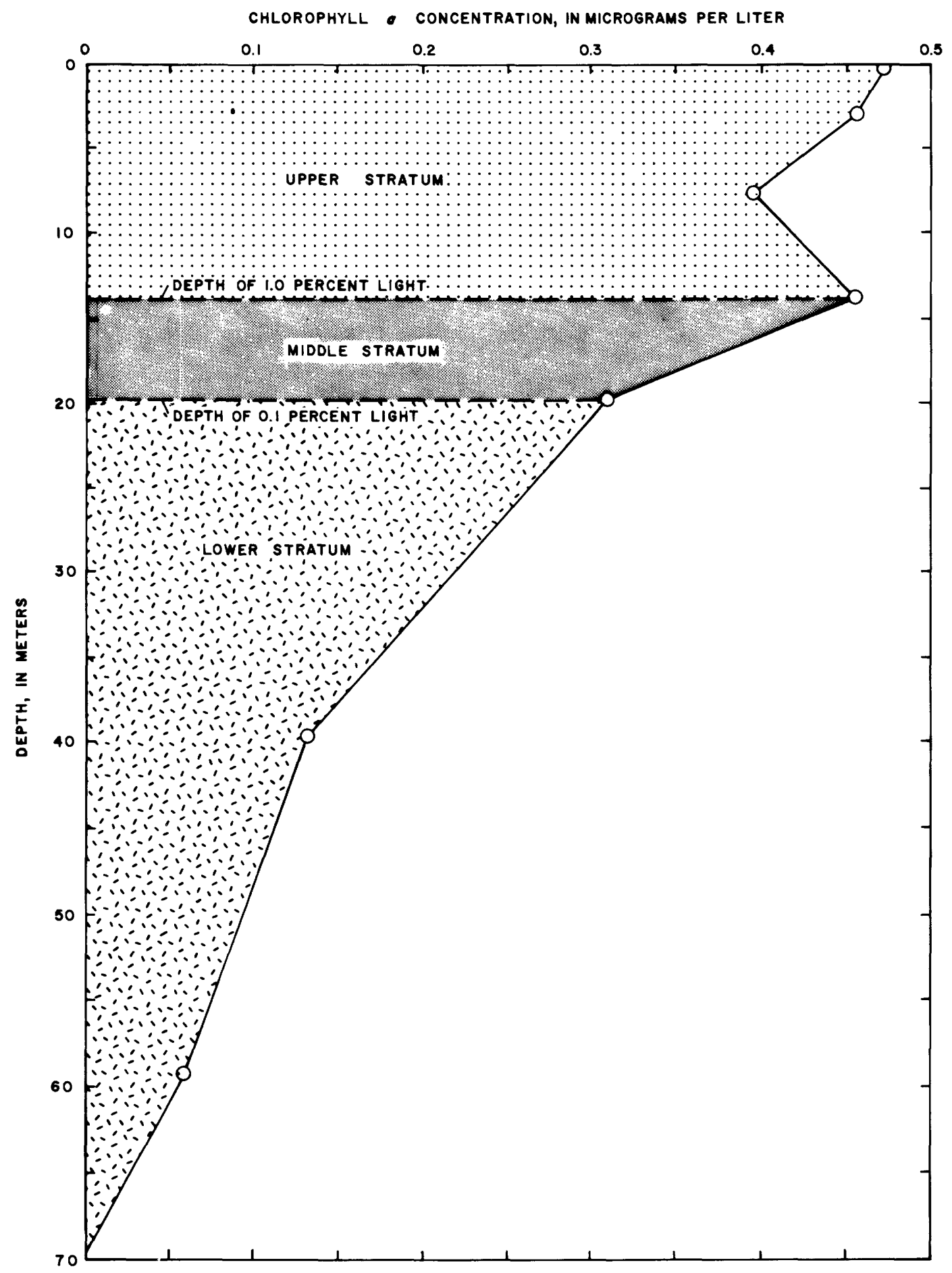

FIGURE 7.-Typical diagram used to quantify the percentage distribution of chlorophyll $a$ within the water column of Lake Koocanusa. 
TABLE 16.-Percentage distribution of chlorophyll a in three depth strata at the Forebay and Tenmile stations in 1980

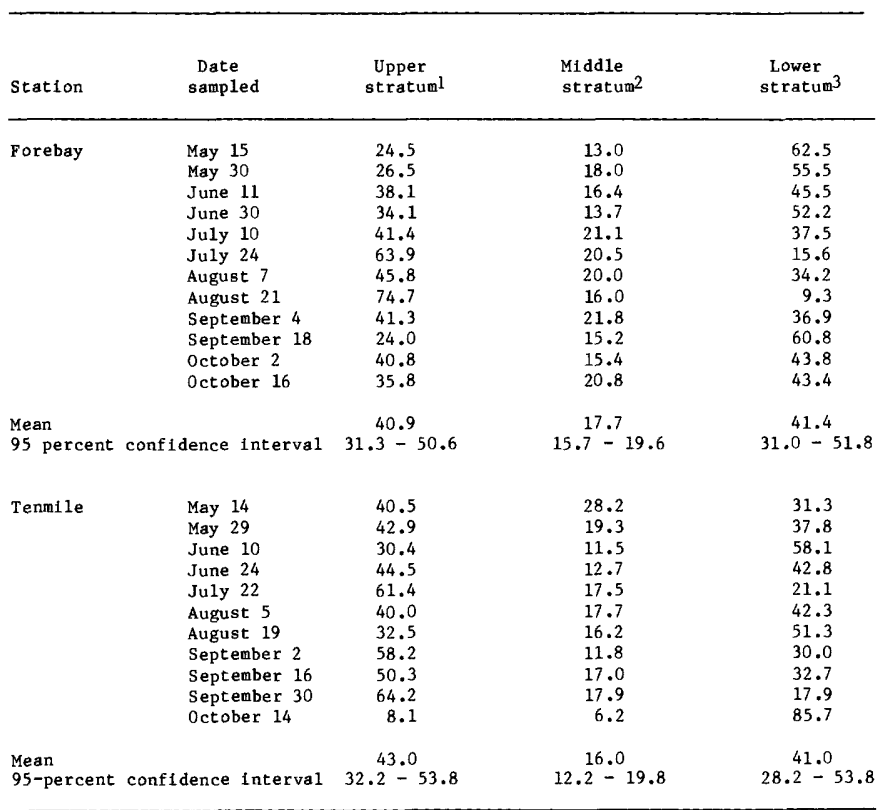

1 Surface to depth of 1.0 percent light

2 Depth of 1.0 percent 1 ight to depth of 0.1 percent 1 ight

${ }^{3}$ Depth of 0.1 percent 11 ght to depth equal to depth of 0.1 percent 11 ght plus onehalf of depth difference between 1.0 and 0.1 percent light depths.

$a$ was contained within the euphotic zone and, thereby, provided evidence that phytoplankton was circulated out of the euphotic zone.

The importance of circulation of phytoplankton out of the euphotic zone in Lake Koocanusa was discussed by Woods (1981). He concluded that the reduction in phytoplankton photosynthesis resulting from reduced light intensities below the euphotic zone was an important factor in suppressing the reservoir's primary productivity to oligotrophic levels.

\section{TROPHIC STATE OF LAKE KOOCANUSA}

The trophic state of Lake Koocanusa can be categorized with one or more of the available trophic state indices. Most indices define discrete ranges for their categories of trophic state. A lake or reservoir generally can be placed within one of the following categories: Oligotrophic, mesotrophic, eutrophic, and hypereutrophic. Comparison of different trophic state indices, however, is often misleading because of the variety of variables used in their development. The use of different variables has arisen, in part, because three general approaches to trophic state determination are recognized. One approach considers nutrient supply as a stimulus to the water body. This approach uses vari- ables such as nutrient concentrations within the water body or nutrient loads delivered to the water body from its drainage basin. The second approach uses the biological condition of the water body as an indicator of its trophic state. This approach uses variables such as primary productivity or chlorophyll $a$ concentrations. The third approach combines the first two approaches to develop multivariate indices of trophic state.

The trophic state of Lake Koocanusa during 1972-80 was determined from data on primary productivity and loadings of total phosphorus and total nitrogen delivered into the reservoir. Primary productivity was used because it is a biological process that integrates the effects of numerous environmental variables controlling production of organic matter. Nutrient loadings were used because they have been emphasized in most studies of the aquatic environment of Lake Koocanusa, and Bonde and Bush (1975) used them to predict the trophic state of the reservoir prior to impoundment. The use of primary productivity and nutrient loadings for predicting trophic state was deemed appropriate in light of the conclusion drawn by Schindler (1978) that the relationship between nutrient supply and algal productivity has been well documented by numerous researchers.

A previous section of this report discussed primary productivity data that were used to classify the trophic state of Lake Koocanusa. The conclusion was drawn that Lake Koocanusa was oligotrophic from $1972-80$ because its average daily areal primary productivity ranged from 63.6 to $105.5 \mathrm{mg} \cdot \mathrm{C} \cdot \mathrm{m}^{-2}$ (table 11 ) and, therefore, was clearly within the range of 50 to 300 $\mathrm{mg} \cdot \mathrm{C} \cdot \mathrm{m}^{-2}$ that Wetzel (1975) considered oligotrophic.

The nutrient loading approach developed by Vollenweider $(1968,1975)$ was the other method used to classify the trophic state of the reservoir. Vollenweider (1968) was able to graphically separate 20 lakes into categories of oligotrophic, mesotrophic, and eutrophic by plotting logarithmic areal totai phosphorus or total nitrogen loading of each lake against its logarithmic mean depth. Mean depth is the quotient of lake volume divided by surface area of the lake. Vollenweider also empirically determined a lower boundary line for permissible loading that quantified the maximum areal loading of total phosphorus or total nitrogen that a lake could receive and remain oligotrophic. Also determined was an upper boundary line for excessive loadings that would yield a eutrophic lake. Vollenweider (1975) modified his original model by adding hydraulic-residence time to allow for hydraulic effects in addition to the effects of nutrient loading and lake morphometry. The boundary lines for permissible and excessive loadings of total phosphorus were revised in the modified model; however, boundaries were not revised for total nitrogen 
because the criteria needed to develop such boundary lines were incomplete (Rast and Lee, 1978).

Data needed to use Vollenweider's model include the yearly areal loading of total phosphorus or total nitrogen and the ratio of mean depth to hydraulic-residence time. Such data for Lake Koocanusa are listed in table 17; the data include 1972 through 1980 and the theoretical values for a reservoir containing $7.16 \mathrm{~km}^{3}$ and discharging an annual outflow of $10.65 \mathrm{~km}^{3}$, which is equal to its mean annual inflow. The theoretical nutrient loadings in table 17 are those reported by Bonde and Bush (1975) in their preimpoundment study of the reservoir.

The trophic state of Lake Koocanusa, based on application of Vollenweider's phosphorus loading model, is depicted in figure 8 . The data in table 17 produced 10 points on figure 8; all 10 were within the eutrophic zone, but they were clustered into two groups. The theoretical value and those for 1972 through 1975 grouped higher into the eutrophic zone than the post1975 group. The post-1975 group was lower than the pre-1975 group as a consequence of the 1976 reduction in phosphorus loading (table 4).

The relationship of areal total nitrogen loading and the ratio of mean depth to hydraulic residence time is depicted in figure 9 for Lake Koocanusa and 34 lakes analyzed by Rast and Lee (1978). The upper and lower boundary lines were not available for delineation of the three regions of trophic state, but the 10 points for Lake Koocanusa clearly occur within the cluster of eutrophic lakes. In contrast to figure 8 , the 10 points were not split into two groups. The occurrence of the points in a single group was a consequence of the lack of reduction in nitrogen loading to the reservoir (table $5)$.

TABLE 17.-Required data for using Vollenweider ${ }^{a}$ nutrient loading models to determine the trophic state of Lake Koocanusa

\begin{tabular}{|c|c|c|c|c|c|}
\hline \multirow[b]{2}{*}{ Year } & \multirow[b]{2}{*}{$\begin{array}{l}\text { Mean depth, } \\
\text { in meters }\end{array}$} & \multirow{2}{*}{$\begin{array}{l}\text { Hydraulic- } \\
\text { residence } \\
\text { time, in } \\
\text { years }\end{array}$} & \multirow{2}{*}{$\begin{array}{l}\text { Ratio of } \\
\text { mean depth to } \\
\text { hydraulic- } \\
\text { yesidence } \\
\text { time, } \\
\text { in meters } \\
\text { per year }\end{array}$} & \multicolumn{2}{|c|}{$\begin{array}{l}\text { Annual areal loading, } \\
\text { In grams per square meter }\end{array}$} \\
\hline & & & & $\begin{array}{l}\text { Total } \\
\text { phosphorus }\end{array}$ & $\begin{array}{c}\text { Total } \\
\text { nitrogen }\end{array}$ \\
\hline 1972 & 23.2 & 0.14 & 165.7 & 15.7 & 61.7 \\
\hline 1973 & 23.9 & .33 & 72.4 & 20.7 & 41.1 \\
\hline 1974 & 30.6 & .29 & 105.5 & 11.9 & 32.4 \\
\hline 1975 & 29.7 & .41 & 72.4 & 10.5 & 22.5 \\
\hline 1976 & 32.6 & .38 & 85.8 & 3.8 & 22.6 \\
\hline 1977 & 30.7 & .50 & 61.4 & 2.8 & 19.3 \\
\hline 1978 & 32.5 & .48 & 67.7 & 3.7 & 21.3 \\
\hline 1979 & 32.8 & .62 & 52.9 & 2.9 & 19.1 \\
\hline 1980 & 33.5 & .58 & 57.8 & 2.9 & 22.1 \\
\hline Theoretical & 138.4 & .67 & 57.3 & $10.0 \mathrm{~b}$ & $20.0 \mathrm{~b}$ \\
\hline
\end{tabular}

avollenwetder (1975)

bFrom Bonde and Bush (1975)
The eutrophic ranking that was derived for Lake Koocanusa from figures 8 and 9 conflicted with the oligotrophic ranking that the reservoir received for its values of primary productivity. The following discussion develops possible explanations for this discrepency in trophic state ranking.

Two recent papers by Winter (1981a, 1981b) have emphasized measurement errors that are associated with water and chemical balances of lakes and reservoirs. Sufficient data were not available for Lake Koocanusa for estimating the magnitude of such errors for computations of annual areal loadings of total phosphorus and total nitrogen. However, the effect of these errors on the categorization of trophic state can be visualized with figures 8 and 9. If the annual areal loadings of total phosphorus in table 17 were assumed to be double their true values, the downward shifts in the 10 points that would be plotted on figure 8 for the true values still would be inadequate to place the reservoir into the oligotrophic zone. A similar conclusion was drawn for annual areal nitrogen loadings depicted in figure 9. Undoubtedly, errors existed in the water and chemical balances computed for both the reservoir and its various sources of inflow, but these errors did not fully account for the discrepency in trophic state.

Only part of the nutrient loading that enters a lake or reservoir may become available to phytoplankton in the euphotic zone if the lake or reservoir experiences significant amounts of stratified interflow or underflow beneath the euphotic zone (Rast and Lee, 1978). Inflow to Lake Koocanusa during its annual filling phase was routed primarily as interflow or underflow (Woods, 1979). During the filling of Lake Koocanusa, the monthly loadings of total phosphorus and total nitrogen were at their largest for the year (Woods and Falter, 1982). Hence, some of the reservoir's nutrient supply may have been inaccessible to phytoplankton in the euphotic zone.

In addition to this hydrodynamic loss of nutrients, another part of the influent loading of total phosphorus may have been adsorbed and deposited by suspended sediment. Iskandar and Shukla (1981) concluded that Lake Koocanusa sediments functioned as a phosphorus sink.

The hydrodynamic and sedimentation processes within the reservoir help explain why potentially eutrophic nutrient loadings failed to stimulate primary productivity to eutrophic levels. However, the primary productivity of the reservoir was not solely controlled by nutrient supply; physical limnological processes contributed to the suppression of primary productivity to oligotrophic levels (Hobbie, 1976; Bush and Bonde, 1977; Woods, 1979, 1981). The essence of the reports by these authors is that the weak thermal structure of Lake 


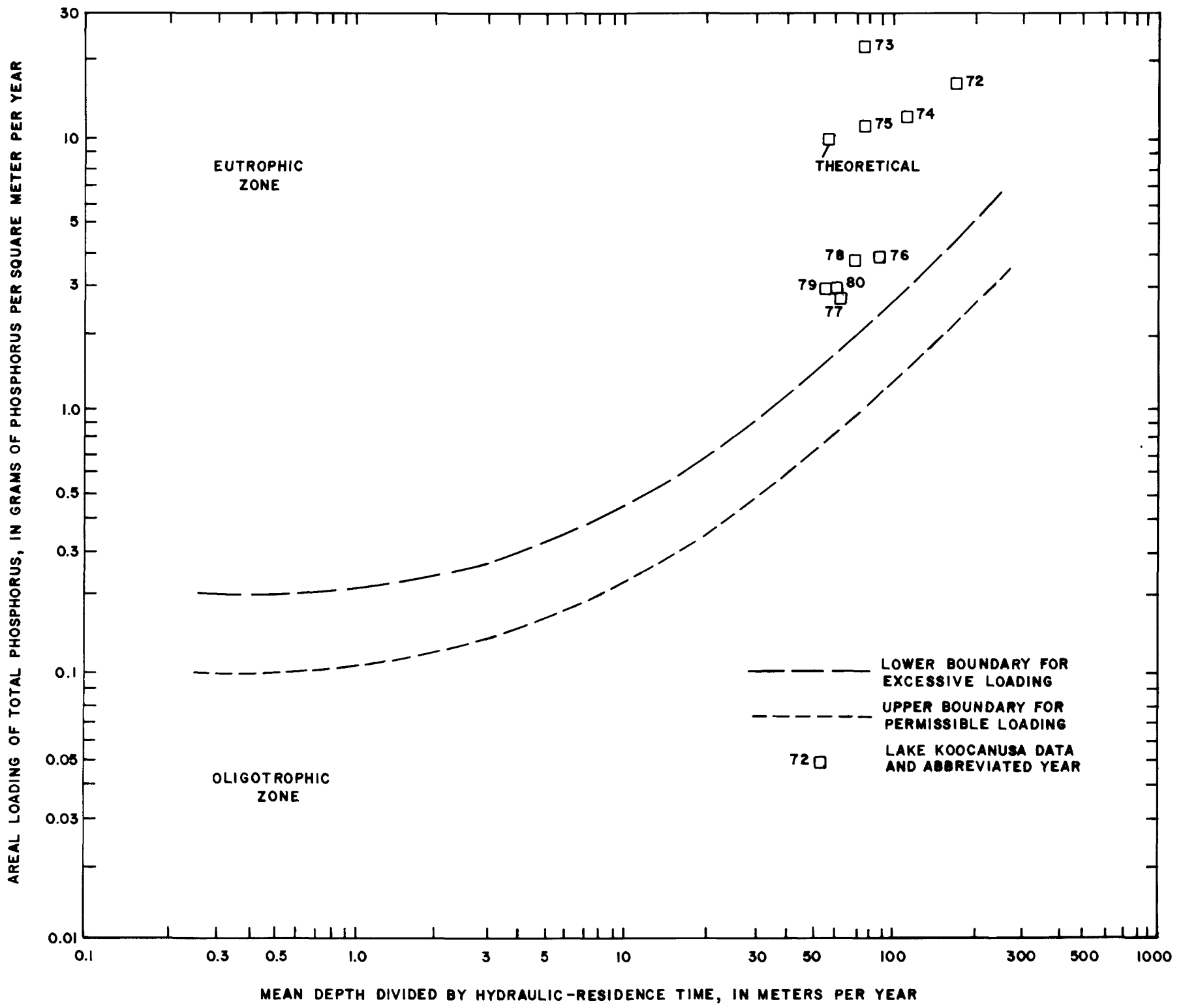

FIGURE 8.-Application of Lake Koocanusa data in table 17 to Vollenweider total phosphorus loading and mean depth/hydraulic-residence time diagram. Illustration modified from Rast and Lee (1978).

Koocanusa allowed circulation of phytoplankton out of an often shallow euphotic zone. Circulation into poorlight conditions reduced phytoplankton photosynthesis and, hence, annual primary productivity.

One can conclude that physical processes within Lake Koocanusa were more important in determining its trophic state, based on primary productivity, than was determination of its trophic state based on influent nutrient loadings. This conclusion supports a generalization expressed by Carlson (1979) that the use of nutrient loadings to characterize trophic state fails to consider the actual response of the lake; the nutrient loading method only considers the lake's expected response to external stimuli.

\section{CONCLUSIONS}

Preimpoundment and postimpoundment studies of Lake Koocanusa have generated an extensive data base that has provided insight into the physical, chemical, and biological characteristics of the reservoir and its drainage basin. In these studies, the relationship of nutrient loadings, primary productivity, and trophic state has received much attention, largely because the preimpoundment studies reported large loadings of nitrogen 


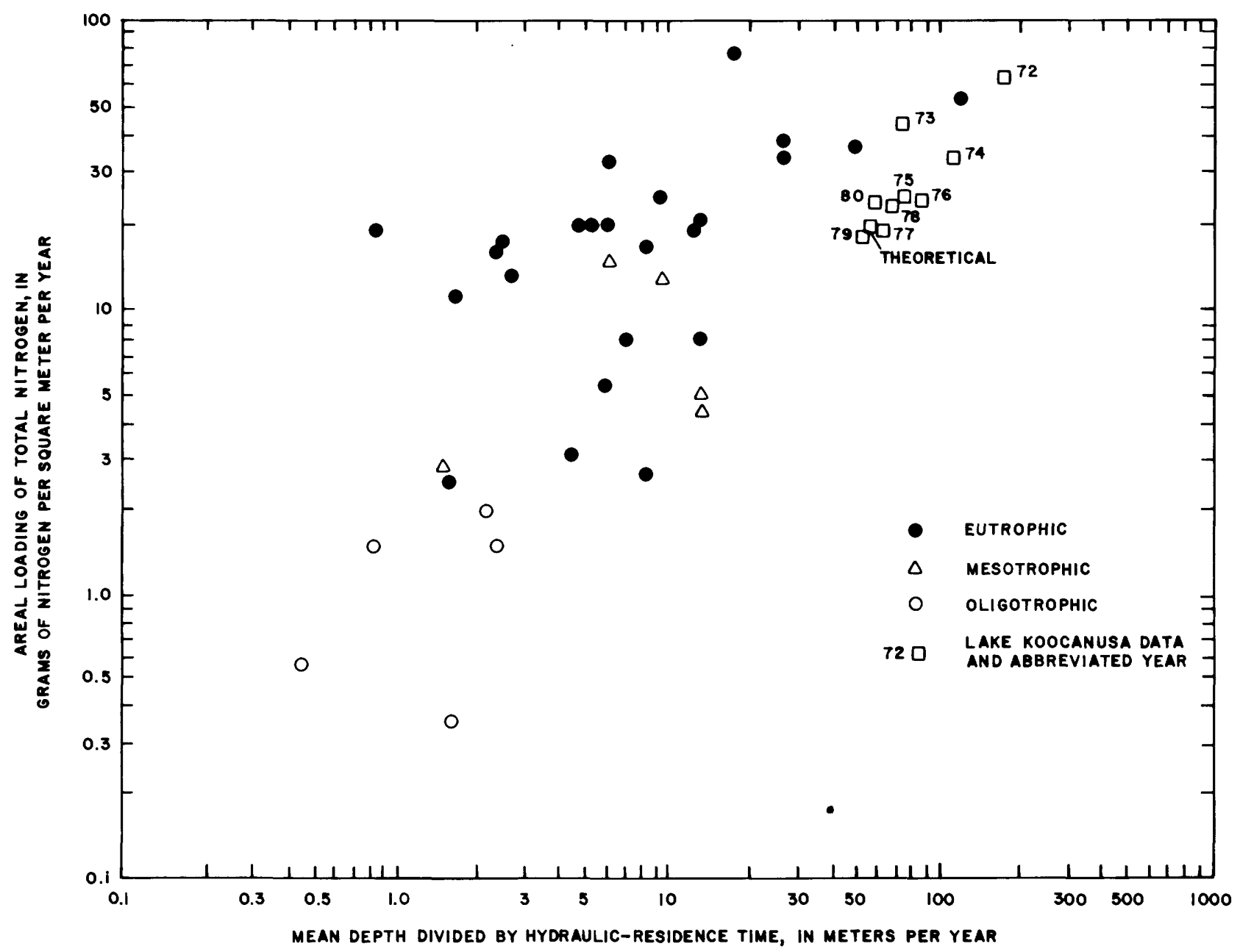

FIGURE 9.-Application of Lake Koocanusa data in table 17 to Vollenweider total nitrogen loading and mean depth/hydraulic-residence time diagram. Illustration modified from Rast and Lee (1978).

and phosphorus that might have caused eutrophication of Lake Koocanusa. During 1972-80, the reservoir was classifiable as eutrophic, based on the relationship of annual areal loadings of total nitrogen or total phosphorus to the ratio of mean depth and hydraulic-residence time. The eutrophic classification was not changed by the substantial reductions in total phosphorus loading that commenced in 1976 as a result of an upstream fertilizer plant instituting improved treatment of its effluent. However, the average daily areal primary productivity in Lake Koocanusa during 1972-80 characterized its trophic state as oligotrophic-in conflict with the eutrophic classification based on nutrientloading data. This discrepency of classification in trophic state is attributed to the failure of nutrient-loading models to adequately account for limnological processes within Lake Koocanusa, which affected the avail- ability of influent nutrient loadings to phytoplankton.

Previous studies of limnological processes in Lake Koocanusa reported a weak thermal structure and, therefore, hypothesized that phytoplankton was circulated out of the euphotic zone. Such circulation was verified by a study of chlorophyll $a$ distribution, which revealed that more than one-half of the reservoir's phytoplankton was located beneath the euphotic zone. Multiple regression analysis demonstrated that mean annual euphotic zone depth was an important predictor of annual areal primary productivity.

The relationship of daily values of primary productivity and concurrent values for physical, chemical, and biological variables was not studied in this project. Such an evaluation likely would yield valuable insight into the reasons why Lake Koocanusa was oligotrophic during $1972-80$. 


\section{REFERENCES}

Bonde, T. J. H., 1979, Pre- and post-impoundment studies of the Kootenai River: Unpublished paper presented at the 109th annual meeting of the American Fisheries Society, West Yellowstone, Montana, September 14, 1979, 12 p.

Bonde, T. J. H., and Bush, R. M., 1975, Kootenai River water quality investigations, Libby Dam preimpoundment study, 1967-1972: U.S. Army Corps of Engineers, Seattle District, 124 p.

Brune, G. M., 1953, Trap efficiency of reservoirs: American Geophysical Union Transactions, v. 34, no. 3, p. 407-418.

Bush, R. M., and Bonde, T. J. H., 1977, Relating water quality to the aquatic environment: Libby Dam-Lake Koocanusa project case study: Proceedings of a seminar on water quality data collection and management, Denver, Colorado, January 25-26, 1977, $10 \mathrm{p}$.

Carlson, R. E., 1979, A review of the philosophy and construction of trophic state indices, in Maloney, T. E., ed., Lake and reservoir classification systems : U.S. Environmental Protection Agency, EPA-600/3-79-074, p. 1-52.

Coffin, D. L., 1970, A preliminary evaluation of bank storage associated with Libby Reservoir in northwestern Montana: U.S. Geological Survey Water- Supply Paper 1899-L, 25 p.

Crozier, R. J., and Leinweber, L. R., 1975, Libby Dam preimpoundment study: Nelson, British Columbia, British Columbia Pollution Control Branch, $166 \mathrm{p}$.

Daley, R. J., Carmack, E. C., Gray, C. B. J., Pharo, C. H., Jasper, S., and Weigand, R. C., 1981, The effects of upstream impoundments on the limnology of Kootenay Lake, B. C.: Vancouver, British Columbia, Department of Environment, Inland Waters Directorate, $242 \mathrm{p}$.

Dillon, P. J., and Rigler, F. H., 1974, A test of a simple nutrient budget model predicting the phosphorus concentration in lake water: Journal of the Fisheries Research Board of Canada, v. 32 , p. $1777-1778$.

Draper, N. R., and Smith, H., 1966, Applied regression analysis: New York, John Wiley and Sons, 407 p.

Fogg, G. E., 1974, Nitrogen fixation, in Stewart, W. D. P., ed., Algal physiology and biochemistry: Berkeley, University of California Press, p. 560-582.

Golterman, H. L., 1975, Physiological limnology: Amsterdam, Elsevier Scientific Publishing Co., 489 p.

Greeson, P. E., Ehlke, T. A., Irwin, G. A., Lium, B. W., and Slack, K. V., 1977, Methods for collection and analysis of aquatic biological and microbiological samples: U.S. Geological Survey Techniques of Water-Resources Investigations, Book 5, Chapter A4, $332 \mathrm{p}$.

Hobbie, J. E., 1976, Limnology of Lake Koocanusa, Montana, in McKim, H. L., Gatto, L. W., Merry, C. J., Brockett, B. E., Bilello, M. A., Hobbie, J. E., and Brown, J., Limnological Investigations: Lake Koocanusa, Montana, Part 2: Environmental Analyses in the Kootenai River Region, Montana: Hanover, New Hampshire, U.S. Army Corps of Engineers, Cold Regions Research and Engineering Laboratory Special Report 76-13,p.18-22.

Iskandar, I. K., and Shukla, S. S., 1981, Limnological investigations: Lake Koocanusa, Montana, Part 5: Phosphorus chemistry of sediments: Hanover, New Hampshire, U.S. Army Corps of Engineers, Cold Regions Research and Engineering Laboratory Special Report 81-15, 9 p.

Keeney, D. R., 1972, The fate of nitrogen in aquatic ecosystems: University of Wisconsin, Water Resources Center, Eutrophication Information Program, Literature Review No. 3, 59 p.

Lee, G. F., 1970, Factors affecting the transfer of materials between water and sediments: University of Wisconsin, Water Resources Center, Eutrophication Information Program, Literature Review No. 1,50 p.

is U.S. GOVERNMENT PRINTING OFFICE: 1982-576-034/7 Region No. 8
Likens, G. E., 1975, Primary productivity of inland aquatic ecosystems, in Leith, Helmut, and Whittaker, R. H., eds., Primary productivity of the biosphere: New York, Springer-Verlag Inc., p. $185-202$.

Rast, Walter, and Lee, G. F., 1978, Summary analysis of the North American (U.S. portion) OECD eutrophication project: nutrient loading-lake response relationships and trophic state indices: U.S. Environmental Protection Agency, EPA-600/3-78-008, 455 p.

Reckhow, K. H., 1979, Quantitative techniques for the assessment of lake quality: U.S. Environmental Protection Agency, EPA$440 / 5-79-015,146 \mathrm{p}$.

Reckhow, K. H., Beaulac, M. N., and Simpson, J. T., 1980, Modeling phosphorus loading and lake response under uncertainty: A manual and compilation of export coefficients: U.S. Environmental Protection Agency, EPA-440/5-80-011, 214 p.

Rigler, F. H., 1973, A dynamic view of the phosphorus cycle in lakes, in Griffith, E. J., Beeton, A., Spencer, J. M., and Mitchell, D. T., eds., Environmental phosphorus handbook: New York, John Wiley and Sons, p. 539- 572.

SAS Institute, Inc., 1979, SAS user's guide, 1979 edition: Cary, North Carolina, SAS Institute, Inc., $494 \mathrm{p}$.

Schindler, D. W., 1978, Factors regulating phytoplankton production and standing crop in the world's freshwaters: Limnology and Oceanography, v. 23, p. $478-486$.

Slack, K. V., Averett, R. C., Greeson, P. E., and Lipscomb, R. G., 1973, Methods for collection and analysis of aquatic biological and microbiological samples: U.S. Geological Survey Techniques of Water-Resources Investigations, Book 5, Chapter A4, 165 p.

U.S. Department of Commerce, issued annually, Climatological data, Montana.

U.S. Environmental Protection Agency, 1977, Report on Koocanusa Reservoir, Lincoln County, Montana, and British Columbia, Canada, EPA Region VIII: National Eutrophication Survey Working Paper No. 795, $47 \mathrm{p}$.

Vollenweider, R. A., 1968, Scientific fundamentals of the eutrophication of lakes and flowing waters, with particular reference to nitrogen and phosphorus as factors in eutrophication: Paris, Organization for Economic Cooperation and Development, Technical report DAS/CSI/68.27, 250 p.

1975 , Input-output models, with special reference to the phosphorus loading concept in limnology: Schweizerische Zeitschrift Fuer Hydrologie (Swiss Journal of Hydrology) v. 37, p. 53-84.

Water Resources Service, 1976, Kootenay air and water quality study, Phase I, Water quality in Region 4, the Lower Kootenay River Basin: Victoria, British Columbia, Department of Environment, $190 \mathrm{p}$.

Wetzel, R. G., 1975, Limnology: Philadelphia, W. B. Saunders .Co., $743 \mathrm{p}$.

Winter, T. C., 1981a, Uncertainties in estimating the water balance of lakes: Water Resources Bulletin, v. 17, p. 82-115.

$1981 \mathrm{~b}$, Survey of errors for estimating water and chemical balances of lakes and reservoirs, in Stefan, H. G., ed., Proceedings of a symposium on surface water impoundments, v. 1: New York, American Society of Civil Engineers, p. 224-233.

Woods, P. F., 1979, Primary productivity in Lake Koocanusa, Montana: Moscow, University of Idaho, Ph.D. dissertation, $112 \mathrm{p}$.

1981, Physical limnological factors suppressing primary productivity in Lake Koocanusa, Montana, in Stefan, H. G., ed., Proceedings of a symposium on surface water impoundments, v. 2: New York, American Society of Civil Engineers, p. 1368-1377.

Woods, P. F., and Falter, C. M., 1982, Limnological investigations: Lake Koocanusa, Montana, Part 4: Factors controlling primary productivity: Hanover, New Hampshire, U.S. Army Corps of Engineers, Cold Regions Research and Engineering Laboratory Special Report. In press. 